\title{
NEUROFIBROMA ISOLADO NA REGIÃO DE CABEÇA E PESCOÇO: CONSIDERAÇÕES CLÍNICAS E HISTOPATOLÓGICAS
}

\section{LUCIANA SASSA MAROCCHIO}

Dissertação apresentada à Faculdade de Odontologia de Bauru da Universidade de São Paulo, como parte dos requisitos para obtenção do grau de Mestre em Odontologia, área de Patologia Bucal.

(EDIÇÃO REVISADA)

\section{BAURU}

2004 


\section{NEUROFIBROMA ISOLADO \\ NA REGIÃO DE CABEÇA E PESCOÇO: CONSIDERAÇÕES CLÍNICAS E HISTOPATOLÓGICAS}

\section{LUCIANA SASSA MAROCCHIO}

Dissertação apresentada à Faculdade de Odontologia de Bauru da Universidade de São Paulo, como parte dos requisitos para obtenção do grau de Mestre em Odontologia, área de Patologia Bucal.

Orientadora: Profa. Dra. Denise Tostes Oliveira (EDIÇÃO REVISADA)

\section{BAURU}

2004 
Marocchio, Luciana Sassa

M349n Neurofibroma isolado na região de cabeça e pescoço: considerações clínicas e histopatológicas./ Luciana Sassa Marocchio - Bauru, 2004.

xvii , ....p.88: il.; $30 \mathrm{~cm}$.

Dissertação (Mestrado) -- Faculdade de Odontologia de Bauru. Universidade de São Paulo.

Orientador: Profa. Dra. Denise Tostes Oliveira.

Autorizo, exclusivamente para fins acadêmicos e científicos, a reprodução total ou parcial desta dissertação/tese, por processos fotocopiadores e outros meios eletrônicos.

Assinatura:

Bauru, de junho de 2004.

Aprovado pelo Comitê de Ética em Pesquisa da Faculdade de Odontologia de BauruUSP.

Protocolo: 149/2003.

Data: 2 de dezembro de 2003. 


\section{LUCIANA SASSA MAROCCHIO}

Nascimento

Filiação

$1999-2002$

$2003-2004$

Associações
27 de março de 1980

São Paulo - S.P.

Alberto Marocchio Neto

Geanete Aparecida Sassa Marocchio

Curso de Graduação pela Faculdade de Odontologia de Araçatuba.

Mestrado em Patologia Bucal na

Faculdade de Odontologia de Bauru, Universidade de São Paulo.

SBPqO - Sociedade Brasileira de Pesquisas Odontológicas. 
Ei.......SORRIA!!!

Mas não se esconda atrás deste sorriso.

Mostre aquilo que você é, sem medo...

Existem pessoas que sonham!

Viva...

Tente...

Felicidade é o resultado dessa tentativa.

Ei, ame acima de tudo! Ame a tudo e a todos.

Deles depende a felicidade completa.

Procure o que há de bom em tudo e em todos.

Não faça dos defeitos uma distância e, sim uma aproximação.

Aceite a vida, as pessoas.

Faça delas a sua razão de viver.

Entenda os que pensam diferentemente de você.

Não os reprove.

Ei, olhe à sua volta, quantos amigos ...

você já tornou alguém feliz?

Ou fez alguém sofrer com o seu egoísmo?

Ei, não corra !...

Pra que tanta pressa?

Corra apenas para dentro de você.

Sonhe, mas não transforme esse sonho em fuga.

Acredite!

Espere!

Sempre deve haver uma esperança.

Sempre brilhará uma estrela.

Chore!

Lute!

Faça aquilo que você gosta.

Sinta o que há dentro de você.

$\mathrm{Ei}$, ouça ...

Escute o que as pessoas têm a lhe dizer...

É importante!

Faça dos obstáculos degraus para aquilo que você acha supremo.

Mas não esqueça daqueles que não conseguiram subir a escada da vida.

Ei, descubra aquilo de bom dentro de você.

Procure acima de tudo ser gente.

Eu também vou tentar.

Ei, você ...

Não vá embora.

Eu preciso lhe dizer que você pode e deve ser feliz ...

Porque você existe!

\section{CHARLIN CHAPLIN}




\title{
DEDICATÓRIA
}

\author{
À minha querida família: meus pais Alberto e Geanete, meu irmão \\ Guilherme e minha avó Cecília, por transformarem os meus sonhos em \\ sonhos deles, me apoiando incondicionalmente, possibilitando que se \\ tornem reais.
}

"O amor é a única coisa que cresce à medida que se reparte." Exupèry 


\section{À minha orientadora Professora Doutora Denise Tostes}

\section{Oliveira,}

Pela acolhida inicial...entendendo e contendo minha ansiedade

Pela confiança, paciência, amizade, cumplicidade e força constantes

Pela competente e exigente orientação científica

Pelo exemplo de "o que prosperar" e de amor à docência.

Possibilitando um imenso aprendizado profissional e pessoal.

“A felicidade não está no fim da jornada e sim em cada curva que percorremos para encontra-la"

Autor desconhecido 


\section{Ao Doutor Raul Negrão Fleury}

Pelos ensinamentos, pela demonstração constante de amor à Patologia e pela viabilização de parte do trabalho no Instituto de Pesquisa Lauro de Souza Lima...Meu muito obrigado! 


\section{AGRADECIMENTOS ESPECIAIS}

À Deus, pela presença constante, capaz de renovar, a cada momento, a força e a esperança me fazendo crer que tudo valeria à pena...

À minha mestra e amiga Profa. Dra. Renata Callestini, por me apresentar a patologia como um maravilhoso caminho a ser seguido...pela pacienciosa orientação na graduação, convivência, amizade, dedicação e confiança..sempre.

Ao meu querido Antônio Kawagoe dos Santos...por sempre ter estado ao meu lado, apesar das idas e vindas....

Meus sinceros agradecimento aos amigos, irmãos, companheiros, Renata Falchete do Prado e Amélio Borges Taveira...as palavras não são suficientes para demonstrar o amor que sinto por vocês!

À minha querida amiga Maria Renata Sales Nogueira Costa e aos seus familiares, pelo carinho com que me acolheram.

Ao meu querido amigo Renato Vieira de Moraes...minha duplinha...pela amizade e confiança constante

À minha querida amiga Camila de Oliveira Rodini e sua família...pela amizade constante e acolhida tão afetuosa.

As minhas queridas amigas Lidiane de Castro Pinto, Rosário de Arruda Moura Zedebski, Suzana Coelho Figliolia e Marta Miyasawa pela amizade e carinho.

Aos meus companheiros de pós-graduação no departamento de Patologia: Bethânia de Camargo Pinheiro, Renata Bianco Consolaro, Tiago Pinheiro, Andréia Reis da Costa, Erika Raduan, Erick Nelo Pedreira, João Adolfo Costa Hanneman, Leda 
Aparecida Franciscone, Maria Fernanda Martins Ortiz, Patrícia Zambonato de Freitas meu muito obrigado pela convivência amiga, pela compreensão e pelo aprendizado.

Aos funcionários da Disciplina de Patologia da Faculdade de Odontologia de

Bauru, Sras. Fátima e Maria Cristina, Sr. Valdir, Richerland e Oziel agradeço a convivência amiga, apoio, carinho e amizade.

Aos meus amigos de pós-graduação: Aline Aquilante, Darwin Vaz de Lima, Danieli Colaço Siqueira, Danilo Siqueira, Adriana Lustosa,Thaís Acorssi, Carla Ruffeil Moreira, Lígia Bulotto Schidmit, Marcelo Zanda, Renato Yamadeu e Kátia Rodrigues.

"Acaso"

Cada um que passa em nossa vida, passa só, pois cada pessoa é única, e nenhuma substitui a outra. Cada um que passa em nossa vida, passa sozinho, mas não vai só, nem nos deixa só.

Leva um pouco de nós, deixa um pouco de si.

Há os que levaram muito, mas não há os que não deixaram nada. Esta é a maior responsabilidade de nossa vida e a prova de que duas almas não se encontram por acaso...

EXUPÈRY 


\section{AGRADECIMENTOS}

Aos professores da Disciplina de Patologia da Faculdade de Odontologia de

Bauru, Dra. Vanessa Soares Lara, Dr. Luís Antonio de Assis Taveira, Dr. Alberto Consolaro e, especialmente Dra. Denise Tostes Oliveira.

Aos professores da Disciplina de Patologia da Faculdade de Odontologia de Araçatuba, Dra. Renata Callestini, Dra. Ana Maria Pires Soubhia e Dr. Marcelo Macedo Crivellini.

A todos os funcionários da Biblioteca da Faculdade de Odontologia de Bauru pela atenção e presteza oferecidas durante todo o curso.

A Maria Helena Souza Ronchesel pela correção das referências bibliográficas.

A Tânia Mary Cestari pela presteza na montagem das imagens microscópicas.

A Simone Martins Lorena pelo acompanhamento inicial do paciente com neurofibroma plexiforme.

Ao Dr. Cléverson Teixeira Soares pela concessão dos anticorpos e permissão para realização da técnica imuno-histoquímica realizada neste trabalho.

Ao médico Jason Antônio Barreto, do Instituto de Pesquisa Lauro de Souza Lima, pela amizade, paciência e colaboração na conduta clínica do paciente.

A todos os funcionários do Departamento de Patologia do Instituto Lauro de Souza Lima, pelos conhecimentos compartilhados, disposição, auxílio e amizade.

A todos os funcionários da secretaria de Pós-Graduação da Faculdade de odontologia de Bauru, pela presteza com que sempre atenderam minhas solicitações. 


\section{AGRADECIMENTOS INSTITUCIONAIS}

À Direção da Faculdade de Odontologia de Bauru, Universidade de São Paulo, na pessoa as Diretora, Professora Doutora Maria Fidela de Lima Navarro.

À Comissão de Pós-Graduação da Faculdade de Odontologia de Bauru, na pessoa do Presidente, Professor Doutor José Carlos Pereira

Ao coordenador do curso de Pós-Graduação em Patologia Bucal, Professor Doutor Alberto Consolaro.

À CAPES, pelo auxílio pecuniário. 


\section{SUMÁRIO}

LISTA DE FIGURAS X xiii

LISTA DE TABELAS $\quad$ xv

LISTA DE ABREVIATURAS E SÍMBOLOS xvi

RESUMO Xvii

1 INTRODUÇÃO 2

2 REVISÃO DA LITERATURA 6

2.1 Neurofibromas na região de cabeça e pescoço 6

2.1.1 Características clínicas $\quad 12$

2.1.2 Características microscópicas $\quad 15$

2.1.3 Associação com síndromes $\quad 20$

2.1.4 Manifestações bucais $\quad 25$

3 PROPOSIÇÃO 30

4 MATERIAL E MÉTODOS 32

4.1 Obtenção e seleção da amostra 32

4.2 Registro dos dados clínicos e microscópicos 32

4.3 Análise dos dados $\quad 34$

4.4 Registro fotográfico 34

4.5 Caso clínico 34

5 RESULTADOS 38

5.1 Características clínicas da população de estudo 38

5.2 Análise microscópica 44

5.3 Caso clínico 
6 DISCUSSÃO

7 CONCLUSÃO

ANEXOS

REFERÊNCIAS BIBLIOGRÁFICAS

ABSTRACT 


\section{LISTA DE FIGURAS}

FIGURA 1 - Formulário utilizado para a coleta dos dados clínicos e microscópicos relativos aos 43 pacientes portadores de neurofibroma na região de cabeça e pescoço.

FIGURA 2 - Neurofibroma localizado na derme (A) com organização microscópica difusa (A) ou em feixes (B). (H.E., aumento original: $A=50 x ; B=100 x)$.

FIGURA 3 - Neurofibroma difuso na submucosa com nítida separação entre a lesão e a lâmina própria $(\mathrm{A})$. Em $\mathrm{B}$, presença de corpúsculos de Wagner Meisnner-like. (H.E., aumento original: $A=50 x ; B=400 x$ )

FIGURA 4 - Neurofibroma plexiforme na mucosa bucal com organização característica de feixes nervosos cortados transversalmente (A). Em B, observar a presença de corpúsculos Vater-Pacini like. (H.E., aumento original: $\mathrm{A}=100 \mathrm{x} ; \mathrm{B}=400 \mathrm{x}$ )

FIGURA 5 - Observar a distribuição das células fusiformes no interior de um neurofibroma difuso (A) e a presença de pequenos feixes nervosos cortados transversalmente (B). (H.E., aumento original: $A=100 x ; B=400 x$ )

FIGURA 6 - Além da intensa vascularização sanguínea (A), diversos mastócitos foram observados nos neurofibromas da região de cabeça e pescoço (B).(H.E., aumento original : $A=50 x$; $\mathrm{B}=1000 \mathrm{x}$ ) 
FIGURA 7 - Neurofibroma plexiforme localizado na mucosa bucal com

o arranjo histológico de feixes nervosos expandidos dispostos no tecido conjuntivo frouxo. (H.E., aumento original: $\mathrm{A}$ e $\mathrm{B}=128 \mathrm{x})$.

FIGURA 8 - Observar a disposição celular no neurofibroma plexiforme (A) e em B, presença de corpúsculos semelhantes aos de Wagner-Meissner no interior do feixe nervoso expandido. (H.E., aumento original: $A=100 x ; B=400 x$ )

FIGURA 9 - Imunomarcação da proteína S-100 no neurofibroma plexiforme (A). Em B, detalhe de algumas células imunopositivas a este anticorpo (Imuno-histoquímica: S100, aumento original: $\mathrm{A}=50 \mathrm{x} ; \mathrm{B}=1000 \mathrm{x}$ )

FIGURA 10 - A imunomarcação para o EMA (A) e colágeno IV (B) no neurofibroma plexiforme. (Imuno-histoquímica: EMA e colágeno IV, aumento original: $\mathrm{A}$ e $\mathrm{B}=50 \mathrm{x}$ )

FIGURA 11 - Imunomarcação da proteína CD34 com marcante imunopositividade das células fibroblásticas.(Imunohistoquímica: $\mathrm{CD} 34$, aumento original: $\mathrm{A}=50 \mathrm{X} ; \mathrm{B}=400 \mathrm{x}$ ) 


\section{LISTA DE TABELAS}

TABELA 1 - Diferenças clínicas e microscópicas entre neurofibroma e schwannoma

TABELA 2 - Distribuição dos neurofibromas da região de cabeça e pescoço nos 43 pacientes da amostra quanto aos critério de inclusão estabelecidos. Faculdade de Odontologia de Bauru USP e Instituto de Pesquisa Lauro de Souza Lima, 1970 a 2003.

TABELA 3 - Distribuição de frequência dos pacientes com neurofibromas na região de cabeça e pescoço segundo os dados demográficos. Faculdade de Odontologia de Bauru/USP e Instituto de Pesquisa Lauro de Souza Lima, 1970 a 2003.

TABELA 4 - Distribuição de freqüência dos pacientes com neurofibromas na região de cabeça e pescoço segundo o diagnóstico clínico estabelecido. Faculdade de Odontologia de Bauru/USP e Instituto de Pesquisa Lauro de Souza Lima, 1970 a 2003.

TABELA 5 - Distribuição de freqüência dos pacientes com neurofibromas na região de cabeça e pescoço segundo a história clínica. Faculdade de Odontologia de Bauru/USP e Instituto de Pesquisa Lauro de Souza Lima, 1970 a 2003.

TABELA 7 - Distribuição de freqüência dos neurofibromas na região de cabeça e pescoço segundo as características microscópicas avaliadas. Faculdade de Odontologia de Bauru/USP e Instituto de Pesquisa Lauro de Souza Lima, 1970 a 2003. 


\title{
LISTA DE ABREVIATURAS
}

\author{
$\mu \mathrm{m} \quad$ Micrometro \\ $\mathrm{mM} \quad$ Milimolar \\ bFGF/FGF- fator de crescimento fibroblástico básico \\ CD34 glicoproteína presente em células hematopoiéticas e endoteliais imaturas \\ DAB substrato cromógeno diaminobenzidina \\ DNA ácido desoxirribonucléico \\ EMA Antígeno epitelial de membrana \\ ${ }^{\circ} \mathrm{C} \quad$ graus Celsius \\ FISH hibridização in situ com fluorescência \\ $\mathrm{H}_{2} \mathrm{O}_{2} \quad$ peróxido de hidrogênio \\ HE hematoxilina e eosina \\ kDa- $\quad$ Kilodalton \\ Leu-7 determinante antigênico encontrado principalmente em células Natural Killer \\ $\mathrm{LOH} \quad$ perda da heterozigoze \\ LSAB reagentes de marcação da técnica estreptavidina- biotina . \\ MAG glicoproteína- associada à mielina \\ NF-1 neurofibromatose-1 \\ NF-2 neurofibromatose-2 \\ NGF fator de crescimento neural \\ OMS Organização Mundial da Saúde \\ p-16 gene supressor de tumor \\ p-21-Ras Proteína transdutora de sinais celulares \\ p-27-kip1 Proteína inibitória da ciclina dependente da quinase \\ p-53 gene supressor de tumor \\ PAS ácido periódico de Schiff \\ PBS tampão fosfato \\ $\mathrm{pH} \quad$ potencial hidrogeniônico \\ USA Estados Unidos da América \\ S-100 Proteína cálcio-ligante altamente ácida
}




\section{RESUMO}

Os neurofibromas ocorrem na região de cabeça e pescoço como lesões, isoladas ou múltiplas, freqüentemente associadas às síndromes das neurofibromatoses. $\mathrm{O}$ objetivo deste trabalho consistiu em avaliar os aspectos clínicos e microscópicos dos neurofibromas, particularmente a variante plexiforme, na pele da região de cabeça e pescoço e na mucosa bucal e discutir a patogênese e as condutas clínicas dessas lesões, quando de sua ocorrência isolada não associada a neurofibromatose-1 (NF-1). Nossa amostra foi selecionada a partir dos neurofibromas na região de cabeça e pescoço diagnosticados no período entre 1973 a 2003 pelos Serviços de Anatomia Patológica do Departamento de Estomatologia - Área de Patologia da Faculdade de Odontologia de Bauru/USP e do Instituto de Pesquisa Lauro de Souza Lima. Os dados demográficos e a história clínica das lesões foram obtidos pela análise do prontuário do paciente. Um total de 66 neurofibromas foram avaliados microscopicamente em coloração de rotina sendo registradas algumas características como a morfologia celular, a organização histológica da lesão, a presença e distribuição do infiltrado inflamatório, da vascularização sanguínea, bem como, a presença de mastócitos e corpúsculos táteis-like. Nossos resultados demonstraram uma maior freqüência de lesões cutâneas $(81,8 \%)$ se comparadas à mucosa bucal (18,2\%), manifestando-se principalmente em indivíduos do gênero feminino e na faixa etária acima de 40 anos. Uma maior ocorrência de lesões únicas, isoladas $(51,2 \%)$ foi observada na pele e mucosa bucal, sendo as lesões múltiplas $(37,2 \%)$ quase sempre associadas a NF-1 clinicamente comprovada em 12 pacientes $(28,0 \%)$. Na boca, as lesões foram encontradas em $27,9 \%$ dos casos, sendo o local mais afetado a mucosa gengival e rebordo alveolar. Dos dois neurofibromas plexiformes observados, ambos na mucosa bucal, apenas um estava associado a NF-1. Microscopicamente, a variante difusa foi predominantemente observada sobre a plexiforme sendo encontrados inclusive corpúsculos táteis-like. Nossos resultados demonstraram que os neurofibromas isolados, particularmente a variante plexiforme, embora observados comumente na pele, podem ocorrer também na mucosa bucal sem associação com a NF-1. O comportamento clínico benigno do neurofibroma isolado na região de cabeça e pescoço e a ausência da associação com a NF-1 sugere uma natureza hamartomatosa para estas lesões, cuja patogênese precisa ser melhor investigada. 
Introdução 


\section{INTRODUÇÃO}

O neurofibroma consiste em um tumor benigno de origem neural composto por vários componentes como células de Schwann, células perineurais-like, fibroblastos e células intermediárias imersos em uma matriz rica em colágeno e mucina ${ }^{6,17,24,34,44,56}$. Essa lesão pode ocorrer em qualquer parte do corpo, sendo comumente encontrada na pele, nervos profundos ou em associação com tecidos retroperitoneais ${ }^{15,17}$.

Aproximadamente $25 \%$ dos neurofibromas ocorrem na região de cabeça e $\operatorname{pescoço~}^{32,35}$ e desses, aproximadamente $6,5 \%$ se manifestam na cavidade bucal ${ }^{45}$,como lesão isolada ou múltiplas, esta última quase sempre associada às neurofibromatoses $6,15,16,24,45,56$.

As neurofibromatoses consistem em um grupo de doenças neurocutâneas, com padrão de herança autossômica dominante, que diferem entre si geneticamente, microscopicamente e clinicamente ${ }^{15,17,30,34,43,42,44}$. As duas principais manifestações das neurofibromatoses incluem ${ }^{30}$ : a Neurofibromatose tipo 1 (NF-1), também denominada doença de von Recklinghausen associada à alteração estrutural no braço longo do cromossomo $17^{30,34,42,55}$ e a Neurofibromatose tipo 2 (NF-2) também conhecida como 
neurofibromatose acústica ou central determinada por uma alteração genética no braço curto do cromossomo $22^{18,30,34,42}$.

Clinicamente os neurofibromas manifestam-se como nódulos cutâneos ou mucosos, assintomáticos, de crescimento lento e assumem três padrões de crescimento 15,24,44: localizado, difuso e plexiforme, esta última variante considerada um estigma da NF-1 $15,16,25,29,30,31,34,44,59$. Os neurofibromas plexiformes principalmente quando associados a NF-1 envolvem feixes nervosos maiores causando expansão e deformação, ocasionando dor e disfunções neurológicas ${ }^{34}$. Essa variante apresenta uma maior probabilidade de transformação maligna ${ }^{15,26,29,34,37,44}$.

Embora existam poucas informações sobre a real freqüência de neurofibromas isolados não associados às neurofibromatoses, na cavidade bucal, as lesões ocorrem principalmente na língua $8,16,31,41,45,47,49.59$, mas têm sido descritas também na gengiva ${ }^{8,41,45}$, no palato ${ }^{38,41,45,48}$ nas glândulas salivares maiores ${ }^{2,13,51}$ e no interior dos ossos maxilares $5,6,39,41,49$.

A patogênese dos neurofibromas, se consistem em lesões neoplásicas ou hiperplásicas, permanecem sem resposta ${ }^{44}$. Quando associada a NF-1, a patogênese tem sido relacionada à inativação dos dois alelos do gene NF-1 nas células de Schwann causando a perda da neurofibromina e conseqüentemente a indução ao desenvolvimento neoplásico ${ }^{34,37,43,60}$. A transformação quase imperceptível de um neurofibroma preexistente para neoplasia maligna neural reforça sua natureza neoplásica. Por outro lado, os neurofibromas isolados não associados a NF-1 geralmente apresentam 
comportamento clínico benigno e bom prognóstico com baixa probabilidade de transformação maligna reforçando sua natureza hiperplásica ${ }^{34,37,44}$.

A partir de um caso de neurofibroma isolado em mucosa bucal, propusemos a realização de um estudo sobre os aspectos clínicos e histopatológicos dos neurofibromas cutâneos e mucosos na região de cabeça e pescoço. Esses conhecimentos visam contribuir com as condutas clínicas e patogênese dessa lesão, particularmente da variante plexiforme, quando de sua manifestação isolada na boca. 
Revisão de Literatura 


\section{REVISÃO DA LITERATURA}

\section{1 - Neurofibromas na região de cabeça e pescoço}

Os neurofibromas são tumores benignos originados da bainha dos nervos periféricos $^{45}$, que ocorrem em qualquer parte do corpo $^{33}$ sendo comumente encontrados na pele, nervos profundos e em associação com tecidos retroperitoneais $^{31,56}$. Ocorrem como lesões isoladas ou múltiplas, esta última como manifestação das síndromes da NF-1 ou NF-2 $2^{8,31,33,34,44,48}$.

Aproximadamente $25 \%$ dos neurofibromas são encontrados na região de cabeça e pescoço ${ }^{31,34}$, desses $6,5 \%$ ocorrem na cavidade bucal ${ }^{44}$. As lesões podem se originar do nervo facial, do nervo glossofaríngeo, do nervo vago, do nervo hipoglosso, bem como, da cadeia simpática, do plexo cervical ou do plexo braquial $^{31,34}$.

No passado, tanto o schwanoma como o neurofibroma eram referidos como lesões benignas da bainha neural, entretanto, atualmente o diagnóstico entre os dois tumores tornou-se clinicamente importante não apenas para confirmação da presença de uma síndrome, mas também para exclusão de tumores malignos originados da bainha neural ${ }^{43}$. As principais características clínicas e microscópicas utilizadas para distinção entre neurofibroma e schwanoma podem ser visualizadas na Tabela 1. 
TABELA 1- Diferenças clinicas e microscópicas entre neurofibroma e schwannoma

\begin{tabular}{|c|c|}
\hline NEUROFIBROMA & SCHWANNOMA \\
\hline Identificação infreqüente do feixe nervoso & Feixe nervoso sempre identificado \\
\hline Incorporado ao nervo & Excêntrico ao nervo \\
\hline Freqüentemente solitário & Geralmente solitário \\
\hline Envolve principalmente o tronco & Afeta principalmente as extremidades \\
\hline Globular, fusiforme ou difuso & Globular \\
\hline Associado à NF-1 & Não associado à NF-1 \\
\hline Não associado à NF-2 & Ocasionalmente associado à NF-2 \\
\hline Marrom-acinzentado, opalescente & Marrom-amarelado, opaco \\
\hline Consistência firme & Consistência de mole a firme \\
\hline $\begin{array}{l}\text { Delicadamente circundado pelo perineuro e } \\
\text { epineuro (solitário e plexiforme); ausência de } \\
\text { cápsula (difuso) }\end{array}$ & Encapsulado \\
\hline Não apresenta formações císticas & Ocasionais formações císticas \\
\hline Celularidade de baixa a moderada & Alta celularidade \\
\hline $\begin{array}{l}\text { Padrão microscópico unifásico com gradual } \\
\text { alterações na celularidade }\end{array}$ & $\begin{array}{l}\text { Padrão microscópico bifásico- Antoni } \\
\text { A e B }\end{array}$ \\
\hline Matriz rica em mucina & Mucina escassa ou ausente \\
\hline $\begin{array}{l}\text { Corpúsculos de Wagner Meissner e raros } \\
\text { corpúsculos de Pacini- like }\end{array}$ & Corpúsculos de Verocay \\
\hline Mastócitos freqüentes & Mastócitos raros \\
\hline Axônios quase sempre presentes & Axônios quase sempre ausentes \\
\hline $\begin{array}{l}\text { Composto por células de Schwann, células } \\
\text { perineurais-like, fibroblastos e células } \\
\text { transicionais }\end{array}$ & Composto por células de Schwann \\
\hline $\begin{array}{l}\text { Transformação maligna rara ( } 2 \% \text { dos pacientes } \\
\text { com NF-1) }\end{array}$ & $\begin{array}{l}\text { Transformação maligna extremamente } \\
\text { rara }\end{array}$ \\
\hline
\end{tabular}

Adaptado de Scheithauer BW, Woodruff JM, Erlandson RA. ${ }^{43}$

A histogênese dos neurofibromas tem sido insistentemente investigada durante décadas. Desde os estudos de von Recklinghausen ${ }^{54}$ que considerou os neurofibromas tumores fibrosos e de Verocay em $1910^{51}$ que sugeriu que estas lesões 
originavam-se de componentes da bainha nervosa neuroectodermais, diversas teorias sobre a histogênese dos neurofibromas foram propostas ${ }^{43}$.

A partir do conhecimento da diversidade dos constituintes celulares presentes nos neurofibromas incluindo células de Schwann, células perineurais-like, fibroblastos e células intermediárias e dos componentes não celulares, como as fibras colágenas e a mucina, alguns estudos da histogênese foram baseados principalmente nas técnicas imuno-histoquímicas, ultra-estruturais e genéticas ${ }^{33,43}$.

O principal foco das pesquisas tem sido direcionado para os neurofibromas com crescimento contínuo que se manifestam como parte das síndromes das neurofibromatoses. A busca incessante visando determinar a contribuição de cada tipo celular na gênese e crescimento contínuo da lesão, bem como as consequências específicas das alterações do gene NF-1 no processo de controle de crescimento celular e o papel adicional dos fatores genéticos e biológicos no desenvolvimento tumoral consistem nos principais questionamentos relacionados à patogênese desta lesão ${ }^{33}$.

$\mathrm{Na}$ síndrome da neurofibromatose do tipo 1, os neurofibromas dérmicos e plexiformes apresentam tanto células de Schwann não neoplásicas que retêm um alelo funcional do gene $\mathrm{NF}-1\left(\mathrm{NF}^{+/-}\right)$como células de Schwann neoplásicas que perdem a expressão do gene $\mathrm{NF}-1^{33,42}$. Nestas lesões, outras células como fibroblastos, células perineurais e mastócitos com um alelo funcional do gene NF-1 $\left(\mathrm{NF}^{+/}\right)$também são encontradas. Embora suponha-se que principalmente as células de Schwann com deficiência no gene NF-1 sejam os componentes neoplásicos desse tumor $^{36,42,52,60}$, os mastócitos e fibroblastos com um alelo funcional do gene NF-1 
parecem contribuir com sua tumorigênese $\mathrm{s}^{33,60 .}$

O gene NF1 codifica uma grande proteína citoplasmática denominada "neurofibromina", que funciona parcialmente como um gene supressor de tumor,

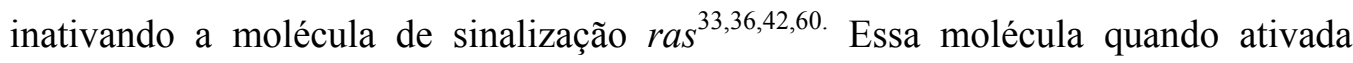
inicia uma cascata de eventos que culmina com a proliferação celular. A neurofibromina funciona inativando o ras e previne seu sinal mitogênico, resultando em proliferação celular reduzida. Portanto, a perda da neurofibromina, como uma conseqüência da inativação dos dois alelos do gene NF-1 nas células de Schwann neoplásicas está associada com elevados níveis de ras-ativado. Em contraste com as células de Schwann, fibroblastos presentes nos neurofibromas não demonstram elevada atividade de ras. No entanto, estudos "in vitro" sugerem que neurofibromas que tenham fibroblastos humanos ou de camundongos com pelo menos um alelo do gene NF-1 alterado (NF1+/-) podem contribuir com a patogênese da lesão ${ }^{33,42}$. Tem sido sugerido que mesmo os fibroblastos não neoplásicos dos neurofibromas não desempenham uma função normal e que provavelmente contribuem com seu desenvolvimento respondendo aberrantemente aos sinais proliferativos enviados pelas células de Schwann neoplásicas ${ }^{33}$.

A contribuição dos mastócitos no desenvolvimento da lesão é pouco conhecida, não havendo, ainda uma função determinada para essa célula ${ }^{33,52}$.

As recentes informações moleculares têm confirmado que as células de Schwann $\left(\mathrm{NF}-1^{-/}\right)$através de seus produtos são as principais responsáveis pela migração dos mastócitos presentes nos neurofibromas ${ }^{52,60}$.

Embora a perda da função do gene NF-1 nas células de Schwann esteja 
associada com a formação do neurofibroma, existem evidências que outros eventos são importantes colaboradores na gênese e o crescimento da lesão ${ }^{33,43}$. Esses eventos incluem a expressão aumentada de receptores e de fatores de crescimento como: o receptor para fator de crescimento derivado de plaqueta, receptor para fator de crescimento epidérmico e fator de crescimento endotelial vascular que pode promover a formação de novos vasos sanguíneos ${ }^{33}$. As propriedades de invasão de vasos sanguíneos das células de Schwann derivadas de neurofibromas podem estar também relacionadas a um aumento de produção de proteínas que quebram a matriz extracelular, como as metaloproteinases, cuja expressão é elevada nos neurofibromas ${ }^{33,43}$.

Em 2003, LARA $^{21}$ ao quantificar os mastócitos e avaliar a expressão bem como a localização do fator de crescimento fibroblástico básico (bFGF) e receptores do fator de crescimento neural (NGFR) em lesões neurais benignas e neuromas traumáticos bucais, constatou que embora em maior número nos neurofibromas, os mastócitos provavelmente contribuem na patogênese destas lesões através de outros mediadores que não o FGF-2 e NGF.

A patogênese dos neurofibromas isolados não associados às síndromes da neurofibromatose, tem sido relacionada muito mais à natureza hiperplásica ou hamartomatosa do que à neoplásica ${ }^{3,14,36,56}$. Segundo PERRY et $\mathrm{al}^{36}$ muitos dos neurofibromas plexiformes sem alterações genéticas detectáveis constituem um grupo de lesões que talvez sejam de fato hiperplásicas por outro lado, esses neurofibromas podem ocultar mutações em outros genes além do NF - 1 ou consistem de tumores com clones neoplásicos que induzem um processo reativo 
incluindo os fibroblastos não neoplásicos, as células perineurais-like e as células de Schwann intraneurais nativas. Então, de acordo com os autores ${ }^{36}$ a determinação da patogênese dessas lesões poderá requerer técnicas sofisticadas capazes de detectar alterações genéticas no interior de células somáticas individuais.

As formas superficiais de neurofibroma, incluindo a variante plexiforme que envolve pequenos nervos na derme ou região subcutânea não são necessariamente patognomônicas da doença de von Recklignhausen, ${ }^{2,3,9,14,31,38,40,43,50,56}$. De acordo com WEISS; GOLDBLUM ${ }^{56}$ lesões pequenas com padrão microscópico plexiforme não devem ser interpretadas como neurofibromas plexiformes com objetivo do estabelecimento do diagnóstico da NF-1

A variante plexiforme do neurofibroma pode ocorrer sem outro estigma da NF-1 $1^{3,14,31,40,46,50}$. Embora a patogênese dessas lesões não esteja completamente esclarecida, acredita-se que elas possam resultar de um mosaicismo do gene NF-1 ou de um outro gene relacionado a este. Testes genéticos para algumas das mutações do gene da NF1 existem entretanto, não há evidência que esses testes poderiam ajudar no diagnóstico desta síndrome em pacientes com neurofibroma plexiforme isolado $^{33,42}$.

Outro aspecto também muito estudado refere-se à tentativa de identificação de eventos genéticos que possam transformar neurofibromas benignos em lesões malignas. A inativação funcional de vários reguladores do ciclo celular como p53, p-27-kip1 e p16 tem sido identificada nas lesões malignas ${ }^{24,25,33}$. A perda da função ou da expressão desses reguladores do ciclo celular resulta em proliferação celular aumentada e pode permitir o acúmulo de mutações genéticas adicionais para o 
processo de malignização ${ }^{24,25,33}$.

A confirmação da célula de Schwann como componente neoplásico foi relatada por PERRY et $\mathrm{al}^{36}$ que verificou a perda da heterozigosidade do gene NF-1 em quatro dos sete neurofibromas plexiformes e em um neurofibroma atípico com deleções restritas as células de Schwann S-100 positivas. Em contraste, todos os oito tumores malignos da bainha neural ocultavam deleções do gene NF-1. Os autores sugeriram que as células S-100 negativas presentes em tumores neurais malignos representam células de Schwann desdiferenciadas que ocultam deleções no gene NF1 nos neurofibromas associados ou não a síndromes.

\subsubsection{Características clínicas}

Os neurofibromas podem estar presentes ao nascimento ou se desenvolver em

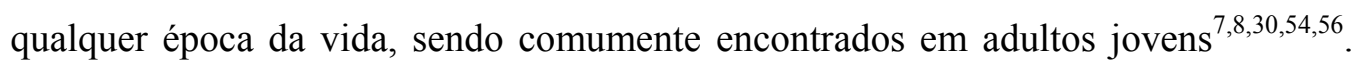
Apresentam-se como nódulos indolores com padrão de crescimento quase sempre imprevisível com períodos de aumento gradual seguido por interrupção aparente do crescimento. A influência hormonal pode modular o crescimento das lesões como demonstrado pelo acentuado desenvolvimento da lesão no período da puberdade e gravidez $^{33,56}$

$\mathrm{Na}$ região de cabeça e pescoço, os neurofibromas podem ser cutâneos, mucosos e relacionados a feixes nervosos profundos. Algumas lesões foram descritas na região cutânea da face e couro cabeludo ${ }^{28,44}$ bem como, em outros locais como boca, laringe e órbita ${ }^{1,34,40,46}$. Os principais feixes nervosos associados à lesão na região de cabeça e pescoço incluem o nervo facial, o glossofaríngeo, o vago e o 
hipoglosso ${ }^{31,34}$.

Os neurofibromas intra-ósseos não apresentam características radiográficas patognomônicas. Geralmente as lesões são observadas como massas grandes, maldefinidas e com densidade variável ${ }^{38,47,48,54}$. A tomografia computadorizada oferece uma densidade imaginológica que varia de acordo com as características histológicas, sendo observadas áreas tênues, semelhantes a cistos ou áreas mais densas; a ressonância magnética oferece imagem com sinais baixos para T1 e altos para T2, com ausência ou diminutas áreas císticas ${ }^{54}$.

Clinicamente os neurofibromas assumem um dos três padrões de crescimento: localizado, difuso ou plexiforme ${ }^{43,55,56}$.

- Neurofibroma localizado -3,55,56 $^{\text {- consiste }}$ na variante mais comumente observada, ocorrendo quase sempre como uma lesão esporádica não associada a síndromes. Freqüentemente surgem em adultos jovens distribuídos em qualquer região da superfície corporal. Clinicamente, apresentam-se como pápulas ou nódulos com características polipóides, assintomáticos e com crescimento lento. A maioria dos neurofibromas localizado se origina de pequenos nervos com extensão para o tecido mole adjacente e embora bem circunscritas essas lesões não são encapsuladas. O neurofibroma localizado pode ser intraneural, afetar qualquer feixe nervoso, espinal ou cranial, da raiz nervosa até pequenas terminações. $\mathrm{O}$ feixe nervoso envolvido torna-se aumentado, fusiforme e segmentado podendo apresentar tamanho diminuto ou grandes dimensões. São 
diagnosticados como aumento volumétrico em tecido superficiais causando sintomas como formigamento ou dor, ou como achados incidentais em exames imaginológicos.

- Neurofibroma difuso - $^{44,55,56}$ - o termo difuso é usado para neurofibroma de grande dimensão, difuso e pobremente definido. Manifesta-se como um espessamento semelhante à placa na derme e tecido subcutâneo na região de cabeça e pescoço, raramente sofrendo transformação maligna. Embora seu padrão de crescimento seja difuso, estruturas como anexos cutâneos, tecido adiposo e muscular são apenas circunscritas e não infiltradas pela lesão. Aproximadamente $10 \%$ dos indivíduos com neurofibromatoses apresentam esta variante ${ }^{43}$.

- Neurofibroma plexiforme $e^{33,43,56}$ - essa variante do neurofibroma é altamente característica e incomum, surgindo durante a infância com tendência a envolver e deformar feixes nervosos maiores. Clinicamente pode causar alterações cosméticas, dor e deficiências funcionais neurológicas. Seu reconhecimento é de grande importância pois ocorre quase exclusivamente em pacientes com a síndrome da neurofibromatose-1 com maior possibilidade de transformação maligna $^{1,33,43,50}$. Quando diagnosticado em pacientes sem história familiar ou outros sinais da NF-1, torna-se interessante realizar uma investigação genética, para a confirmação ou não da NF-1 ou NF-2. Poucos neurofibromas plexiformes isolados não associados à 
síndromes foram descritos na região cutânea ${ }^{3,14}$ e cavidade bucal ${ }^{1,50}$. Embora essa variante apresente maior chance de transformação maligna esse processo raramente tem sido observado nas vísceras, uma vez que estes locais são freqüentemente afetados pela lesão ${ }^{33}$.

O tratamento do neurofibroma solitário localizado ou difuso consiste na remoção cirúrgica ${ }^{6,29,44,56}$, entretanto para o neurofibroma localizado intraneural é necessário o sacrifício do nervo envolvido. A excisão dos neurofibromas plexiformes de grandes dimensões pode causar graves seqüelas neurológicas mas a taxa de recorrência é baixa ${ }^{43}$. Em pacientes sindrômicos, o prognóstico torna-se reservado quanto à recorrência e a possibilidade de transformação maligna ${ }^{28,44,43}$.

\subsubsection{Características microscópicas}

Microscopicamente, os neurofibromas que acometem o tecido cutâneo ou as mucosas da região de cabeça e pescoço, apresentam características básicas peculiares às variantes clínicas das lesões. São compostos por células ovóides ou fusiformes e citoplasma escasso inseridas em uma matriz com quantidade variável de mucina e colágeno, organizadas em pequenos fascículos, enovelados ou em um padrão difusamente distribuído $23,30,32,43,55,56$. As principais células encontradas na lesão consistem:

- Células de Schwann $6,8,13,23,30,32,42,43,44,55,56$ - independente da localização esta consiste no principal componente celular dos neurofibromas, com uma freqüência que varia para mais ou para menos de $50 \%$ da população tumoral. 
- Células perineurais-like e ilhotas de células com diferenciação tátillike $\boldsymbol{e}^{16,22,23,43,56}$ - células perineurais-like distribuem-se variavelmente nas lesões localizando-se perifericamente aos feixes nervosos mielinizados ou não, nas proximidades das células de Schwann ou frouxamente distribuídas na matriz colagênica. São denominadas células perineuraislike porque ao contrário das células perineurais verdadeiras, as perineurais-like não expressam EMA imunorreatividade. Os arranjos celulares semelhantes aos corpúsculos táteis, mais alongados ou lamelares, lembram os corpúsculos de Wagner-Meissner e de VaterPacini, respectivamente, sendo encontrados principalmente nos neurofibromas difusos e plexiformes. Embora os verdadeiros corpúsculos táteis de Meissner e de Pacini sejam formados respectivamente, por células de Schwann e perineurais as características imuno-histoquímicas e ultra-estruturais nos neurofibromas não permitem afirmar que essas estruturas são corpúsculos táteis verdadeiros.

- Fibroblastos ${ }^{33,36,42,43}$ - são estruturalmente idênticos a qualquer outro fibroblasto, no entanto, tem sido sugerido que os fibroblastos do neurofibroma possa contribuir para a sua tumorigênese.

- Células transicionais ${ }^{43}$ - apresentam características de todas as outras células constituintes da lesão, sendo encontradas em número variável e também denominadas células intermediárias. Estudos ultra-estruturais sugerem que esse tipo celular seja híbrido para as características presentes nas células de Schwann, perineural e fibroblastos. 
O padrão do estroma colagênico está relacionado à localização da lesão, apresentando-se geralmente mais frouxamente organizado em neurofibromas periféricos e mais denso em neurofibromas intraneurais ${ }^{43}$. O arranjo intralesional das fibras colágenas também pode ser variável distribuindo-se paralelamente umas as outras, de forma monótona ou de forma difusa, como se estivessem embaralhadas. Em tumores que apresentam fibras nervosas residuais, as células tumorais se dispõem freqüentemente paralelas a direção do feix $\mathrm{e}^{43,55,56}$.

Embora células inflamatórias como linfócitos e macrófagos sejam ocasionalmente encontrados, os mastócitos estão quase sempre presentes em número significativo, podendo somar $5 \%$ de todas as células da lesão, principalmente nos neurofibromas cutâneos ${ }^{23,43}$. O termo neurofibroma atípico tem sido utilizado para lesões com bom prognóstico mas que apresentam atipia nuclear e baixa atividade mitótica $^{25}$, entretanto, não recomendam o uso deste termo pois pode levar a uma confusão no que se refere à transformação maligna.

Uma variante microscópica denominada "neurofibroma pigmentado", devido à presença de pigmentos ultra-estruturalmente e microscópicos semelhantes à melanina, foi descrita por WEISS; GOLDBLUM ${ }^{56}$ em1988, no entanto, devido sua raridade geralmente não se considera uma variante distinta, mas como um achado ocasional $^{43}$.

Um tipo interessante de neurofibroma lipomatoso foi descrito por SHIMOYAMA et $\mathrm{al}^{47}$ caracterizado pela presença predominante de um tecido fibromixóide e $20 \%$ de tecido adiposo na forma de pequenos agregados nodulares ou adipócitos individuais localizados mais distantes da periferia da lesão. 
O neurofibroma plexiforme possui características microscópicas altamente distintas das outras variantes, embora seja mantida a variedade celular. A lesão incipiente apresenta os feixes nervosos poucos celularizados com depósitos de mucina endoneural, conferindo o aspecto microscópico típico de enovelados ${ }^{32,43,44,56}$. Embora presente em todos os neurofibromas, a matriz mucóide é particularmente abundante na variante plexiforme apresentando uma fraca coloração pelo ácido periódico de Schiff (PAS) e uma forte positividade pelo Alcian Blue ${ }^{43}$. Além disso, alguns neurofibromas, principalmente os plexiformes, apresentam nódulos totalmente compostos por células de Schwann, originando estruturas semelhantes aos corpúsculos de Verocay, dificultando o diagnóstico entre o neurofibroma e schwanoma $^{43}$.

Embora reações imuno-histoquímicas não sejam freqüentemente necessárias para o diagnóstico definitivo de neurofibroma, a imunorreatividade a diferentes anticorpos tem sido bem caracterizada.

Todas as variantes do neurofibroma, bem como os corpúsculos táteis-like, apresentam imunopositividade para o anticorpo S-100 $0^{14,36,43,55,56}$. Porém no neurofibroma a positividade a S-100 é variável ${ }^{43}$. Os verdadeiros corpúsculos de Meissner constituídos de camadas de células de Schwann orientadas ao longo das fibras nervosas $^{12}$ são imunorreativos para a proteína S-100 e não apresentam EMAreatividade (Antígeno Epitelial de Membrana) ${ }^{43}$. Também os corpúsculos de Pacini verdadeiros constituídos basicamente por células perineurais distribuídas em lamelas apresentam imunopositividade para o $\mathrm{EMA}^{43}$. Normalmente tanto as células de Schwann envolvidas na formação de mielina como aquelas dos nervos não 
mielinizados são caracterizadas pela forte imunorreatividade para a vimentina e proteína $\mathrm{S}-100^{43}$.

A positividade ao Leu-7 é observada em mais da metade das lesões ${ }^{35}$. Esse é um anticorpo que, além dos linfócitos natural-killer, também reage com as células de Schwann devido a ligação com um epítopo de carboidrato presente na glicoproteína associada a mielina (MAG). Esse epítopo está relacionado à mielinização estando presente na membrana das células de Schwann ${ }^{35}$.

O feixe nervoso com padrão de normalidade contém um perineuro com imunorreatividade para o EMA, um grupo de substâncias de alto peso molecular, pobre em proteínas e rico em carboidratos presente em aproximadamente em todos os epitélios $^{43}$. Apesar da presença de células ultra-estruturalmente semelhantes às perineurais, nem todos os neurofibromas apresentam reatividade celular ao EMA, que ocorre geralmente em lesões com perineuro normal residual, quase sempre comprimido, circundando os feixes nervosos ou na periferia do corpúsculo tátillike $\mathrm{k}^{4,56}$.

A imunorreatividade para o CD-34 é variável, e parece estar relacionada com células que não expressam a reatividade para a proteína S-100 ${ }^{10}$. WEISS e NICKOLOFF $^{56}$ sugeriram que as células imunorreativas ao CD34 podem representar um elemento da bainha neural ainda não descrito que desempenha um papel de suporte para as células de Schwann.

A positividade para o colágeno tipo IV é utilizada para a demonstração da membrana basal. Nos neurofibromas o colágeno tipo IV apresenta-se tipicamente pericelular envolvendo diversas células observadas na matriz ${ }^{10}$. Axônios residuais 
são imunorreativos para neurofilamentos protéicos ${ }^{43}$.

O diagnóstico microscópico diferencial de neurofibroma cutâneo inclui o schwanoma, o tumor maligno da bainha neural de baixo grau de malignidade, o ganglioneuroma, o dermatofibrossarcoma, o mixoma e o neuronevus $\mathrm{s}^{23,43,55,56}$. Na cavidade bucal, além do schwanoma e do mixoma o diagnóstico diferencial deve ser realizado com neuroma traumático, fibroma odontogênico e miofibroma ósseo ${ }^{6,30,32}$.

A importância da distinção microscópica dos neurofibromas está relacionada entre outros fatores, à sua possível associação clínica com algumas síndromes. Por exemplo, os neurofibromas plexiformes são considerados patognomônicos da neurofibromatose do tipo $\mathrm{I}^{29,43,59}$. Além disso, os neurofibromas quando parte de síndromes possuem um potencial maior de malignização ${ }^{16,29,33,36,43}$.

\subsubsection{Associação com síndromes}

Os neurofibromas constituem sinais clínicos importantes das neurofibromatoses, desordens autossômicas dominantes que primariamente afetam o crescimento celular dos tecidos neurais. Essas desordens podem causar crescimentos tumorais em qualquer feixe nervoso e em qualquer local do corpo ${ }^{15,16,33,29,56}$. Algumas manifestações das neurofibromatoses são progressivas resultando em significante morbidade ou mortalidade para o paciente ${ }^{43,56}$.

Em 1987, o National Institutes of Health dos Estados Unidos da América realizou uma conferência sobre neurofibromatose (Consensus Development Conference on Neurofibromatosis), em Bethesda - USA, onde ficou estabelecido que as duas principais manifestações de neurofibromatoses deveriam ser assim 
designadas $^{29}$ :

1. Neurofibromatose 1 ou NF-1 - constitui o tipo mais comum, previamente denominado de Síndrome de von Recklinghausen ou neurofibromatose periférica.

2. Neurofibromatose 2 ou NF-2 - também denominada neurofibromatose acústica ou neurofibromatose central.

A NF-1 é determinada por uma alteração genética no braço longo do cromossomo1 $7^{15,16,17,29,33,36,54}$, gene este que funciona, em parte, como supressor de tumor, atuando na proliferação e diferenciação celular. Afeta 1:4000 indivíduos e embora tenha etiologia autossômica dominante, $50 \%$ dos pacientes não apresentam história familiar ${ }^{41,42,43}$. São considerados patognomônicos dessa síndrome, dois ou mais sinais que incluam ${ }^{29}$ :

- a presença de seis ou mais manchas café com leite com mais de $5 \mathrm{~mm}$ no seu maior diâmetro em crianças ou $15 \mathrm{~mm}$ no maior diâmetro em adolescentes e adultos;

- dois ou mais neurofibromas de qualquer tipo ou um neurofibroma plexiforme;

- $\quad$ sardas nas regiões axilar ou inguinal;

- glioma óptico;

- dois ou mais nódulos de Lisch (hamartomas na íris) que ocorre em 95\% dos pacientes com NF-1 acima de seis anos de idade ;

- uma lesão óssea distinta como displasia esfenóide ou afinamento do córtex dos ossos longos, com ou sem pseudo-artrose;

- um familiar em primeiro grau (pais, irmão(s) ou filho(s)) com neurofibromatose 
estabelecida pelos critérios acima.

A história natural da neurofibromatose-1 é pobremente conhecida mas inclui sérias complicações em alguns indivíduos. Cuidados clínicos para pacientes com NF1 devem envolver os membros da família como um aspecto importante ${ }^{43}$.

Embora os neurofibromas nos portadores de NF-1 possam, ocasionalmente, estar presentes ao nascimento, a maioria das lesões desenvolve-se tardiamente na vida desses pacientes. Tanto nervos periféricos quanto viscerais podem ser afetados por neurofibromas, entretanto pequenos nervos da derme e tecidos subcutâneos são preferencialmente envolvidos ${ }^{29}$.

Clinicamente e morfologicamente, quatro variantes distintas de neurofibroma ocorrem na NF-1 $1^{43,56}$ :

- lesões cutâneas do tipo localizadas e difusas;

- tumores intraneurais localizados em nervos periféricos;

- neurofibromas plexiformes envolvendo tipicamente troncos nervosos,

- neurofibromas massivos de tecido mole (lesão rara, conhecida no passado como "elefantíase neuromatosa", restrita a pacientes portadores da NF-1, que se-manifesta na região cutânea, como um tumor grande e difuso causando gigantismo localizado, principalmente nas extremidades).

Enquanto um neurofibroma solitário de localização intraneural, com grande dimensão originado de uma raiz nervosa é geralmente de ocorrência esporádica, lesões múltiplas estão associadas a NF-1. O mesmo ocorre para os neurofibromas 
cutâneos difusos. Numerosos neurofibromas cutâneos localizados, um do tipo plexiforme e variantes massivas de tecido mole são comumente considerados diagnóstico da síndrome da NF-1 $1^{29,55,56}$.

A NF-2 é determinada por uma alteração genética no braço curto do cromossomo $22^{15,29,33}$, apresentando-se como uma herança autossômica dominante com uma penetrância em torno de $100 \%$ por volta dos 60 anos de idade e afeta 1/50000 indivíduos. Conhecida como neurofibromatose acústica bilateral ou central por apresentar pouca ou nenhuma manifestação periférica, sendo os sintomas dependentes do local exato em que o sistema nervoso foi comprometido. São considerados patognomônicos dessa síndrome ${ }^{29}$ :

- presença de massas bilaterais no oitavo par de nervo craniano detectadas por meio de técnicas de imaginologia (tomografia computadorizada e/ ou ressonância magnética);

- um familiar de primeiro grau com NF-2 e com massa unilateral no oitavo par de nervo craniano, ou duas das seguintes lesões: neurofibroma, glioma, schwanoma, meningioma ou opacidade lenticular subcapsular posterior juvenil.

Ao contrário dos portadores da NF-1, as manchas café-com-leite, quando presentes na NF-2 são pouco numerosas. Além disso, os neurofibromas cutâneos são raros em NF-2, entretanto, os indivíduos desenvolvem múltiplos schwannomas. Nódulos de Lisch não são observados, mas cataratas ocorrem em 60 a 80\% dos portadores dessa síndrome $e^{15,29 .}$

A história natural da neurofibromatose 2 é imprevisível, existem riscos de haver perda de audição e da função vestibular devido a presença de tumores no 
oitavo par de nervos cranianos e de desenvolvimento de neoplasias intra-cranianas e intra-espinhais. A maioria dos pacientes com NF-2 morre das complicações desta síndrome. Deve ser ressaltada a importância da avaliação dos outros membros da família para uma possível detecção da síndrome ${ }^{29}$.

A remoção cirúrgica dos neurofibromas e outras lesões de origem neural presentes na NF-1 e NF-2 deve ser recomendada, entretanto, a localização, o tamanho e a proximidade das lesões com estruturas vitais podem inviabilizar esse tipo de tratamento ${ }^{29,39,44}$. No caso de uma exérese cirúrgica complicada e incompleta a proservação minuciosa do paciente é fundamental, principalmente devido ao risco de transformação maligna dos neurofibromas ${ }^{15,29}$.

$\mathrm{O}$ risco de malignização das lesões da NF-1 envolve basicamente o desenvolvimento de tumores da bainha de nervo periférico ${ }^{16,23,25,26,28,33,36,55,56}$ ocorrendo mais comumente e se originando em uma idade mais precoce quando comparado à população em geral ${ }^{43}$. Estas neoplasias malignas decorrentes da NF-1 são mais freqüentemente localizadas no sistema nervoso central, clinicamente maiores, com comportamento mais agressivo e parecem se originar de um neurofibroma preexistente ${ }^{17,24,26,56,59}$. Os portadores da NF-1 apresentam um gene NF-1 não funcional em cada célula do corpo e acredita-se que os neurofibromas são resultado de uma segunda mutação somática ${ }^{33}$. Entretanto, a transformação maligna dos neurofibromas parece estar relacionada à perda ou mutação de um ou mais genes supressores de tumor. Por exemplo a expressão aberrante do gene p53, um gene supressor de tumor localizado no braço curto do cromossomo 17, tem sido demonstrado na transição de neurofibroma para tumor maligno da bainha de nervo 
periférico $^{17,33,43}$.

Embora a simples presença de um neurofibroma plexiforme tenha sido considerada suficiente para o diagnóstico da NF-1, alguns autores como ALOI;

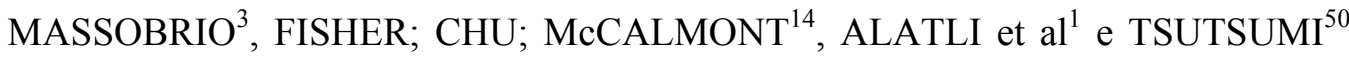
que descreveram lesão de neurofibroma plexiforme isolado em pele e mucosa bucal, respectivamente, em pacientes que não apresentavam sinais da NF-1, questionam a premissa acima.

A ocorrência de um neurofibroma plexiforme em um indivíduo sem outros estigmas da NF-1 ou uma história familiar pode ser o resultado de uma mutação somática local ${ }^{15,33,36,41}$. Este mecanismo parece ser a base da chamada neurofibromatose localizada ou segmental, uma forma de NF-1 onde os neurofibromas e as manchas café-com-leite são limitadas a uma porção do corpo. Este indivíduo não transmite a condição para seus descendentes e as complicações da doença se desenvolvem na região do nervo afetado ${ }^{15,29,41,56}$.

\subsubsection{Manifestações bucais}

O neurofibroma isolado não associado a síndromes surge com frequência variada na região de cabeça e pescoço, porém na cavidade bucal esse tipo de manifestação é incomum, sendo que apenas alguns casos clínicos foram descritos na literatura $^{1,2,5,9,27,37,38,45,46,47,48,49,50}$.

O neurofibroma intrabucal pode ser intra-ósseo ou mucoso. Na mucosa bucal, a língua representa o local mais comumente afetado por esta lesão $0^{8,15,30,40,44,59}$ podendo, no entanto, apresentar extensão para a orofaringe ${ }^{46}$. Além da língua, o 
neurofibroma pode ocorrer também no palato ${ }^{8,37,47}$ e na gengiva ${ }^{1,37}$.

Quando a lesão surge na língua produz uma macroglossia unilateral característica $^{15,44}$ enquanto as gengivais podem causar problemas periodontais crônico. O neurofibroma labial ou localizado na mucosa jugal pode interferir com a fala, a mastigação e expressão facial, tornando a excisão dessa lesão recomendada ${ }^{44}$.

Alguns neurofibromas intra-ósseos ou centrais não associados à neurofibromatose do tipo-1 na época do diagnóstico, foram descritos nos ossos maxilares. Uma ampla revisão destas lesões até o ano de 1970 foi realizada por PRESCOTT; WHITE ${ }^{38}$. As lesões ocorreram predominantemente na mandíbula, algumas vezes, associadas ao canal mandibular. Extensa destruição do osso, do ramo ou ângulo da mandíbula foi observada e os autores ${ }^{38}$ enfatizaram que o aspecto radiográfico desses tumores não é patognomônico podendo simular cistos e tumores odontogênicos, bem como, outros tumores malignos nos maxilares. Portanto, a biópsia é imprescindível para se estabelecer o diagnóstico definitivo de neurofibroma central.

Posteriormente a 1970, outros neurofibromas bucais intra-ósseos isolados não associados a síndromes foram documentados ${ }^{5,13,27,48}$. A mandíbula foi o local mais afetado por essas lesões ${ }^{5,13}$, estando freqüentemente relacionados ao nervo trigêmeo ${ }^{27}$ ou aos seus ramos ${ }^{49}$. SKOUTERIS; SOTEREANOS1 ${ }^{48}$, ao relatarem um caso de neurofibroma intra-ósseo na região posterior da maxila, ressaltaram que os neurofibromas intra-ósseos maxilares apresentam forte predileção pela região posterior, manifestando-se mais comumente em adultos jovens de qualquer gênero, podendo causar dor, disfagia e obstrução nasal. 
Por outro lado, tumores do nervo trigêmeo também são raros podendo causar dor ou parestesia facial, exigindo como relatado por LOUFTY et $\mathrm{al}^{27}$ uma abordagem cirúrgica multidisciplinar para uma completa excisão tumoral, algumas vezes, causando o sacrifício do feixe nervoso envolvido.

Nas glândulas salivares, os neurofibromas ococrrem principalmente nas glândula parótida ${ }^{2,9,13,50}$. De acordo com ALBERNAZ; PRATT; GAREN ${ }^{2}$ um diagnóstico diferencial de neurofibroma em glândula parótida dificilmente é aventado antes da biópsia, devido à ausência de características clínicas patognomônicas dessa lesão, no entanto, pode haver relato de dor, aumento volumétrico da glândula, espasmos e paralisia facial.

TSUTSUMI; TSUNEYUKI; KOMATSUZAK1 ${ }^{50}$ relataram um caso de neurofibroma plexiforme em glândula submandibular, interessante não apenas pela localização da lesão, mas pela variante do neurofibroma e pela constatação da ausência da síndrome. Quanto ao risco de transformação maligna, ELLIS; AUCLAIR; GNEPP ${ }^{13}$ ressaltam que neurofibromas isolados em glândulas salivares possuem menor risco de malignização do que aqueles associados à síndrome da Neurofibromatose que se manifestam no mesmo local.

Além dos neurofibromas intra-ósseos e os associados as glândulas salivares, lesões isoladas na mucosa bucal também foram descritas.

Em 1990, POLLACK ${ }^{37}$ relatou um neurofibroma isolado não associado à síndrome localizado na gengiva marginal palatina do primeiro e segundo molar superior esquerdo associado à presença de uma bolsa periodontal de $6 \mathrm{~mm}$ de profundidade, cujo diagnóstico foi estabelecido pelo exame histopatológico. 
SHARMA; SRINIVASAN ${ }^{46}$ relataram um neurofibroma plexiforme isolado de grande dimensão, que se desenvolveu desde a infância, abrangendo a borda lateral direita do terço médio, o dorso e superfície ventral da língua e estendendo-se para o terço posterior da língua, fossa tonsilar direita incluindo, ambos os pilares, e parede lateral direita da faringe. A paciente foi submetida à excisão cirúrgica da lesão sob anestesia geral e nenhuma outra característica da neurofibromatose do tipo 1 foi detectada.

Assim como os autores anteriormente citados, ALATLI et $\mathrm{al}^{1}$, relataram a presença de um neurofibroma plexiforme isolado aderido ao periósteo na região vestibular do primeiro pré-molar mandibular que causava parestesia, e segundo a paciente havia surgido após anestesia local para um preparo protético. Interessantemente, durante o ato cirúrgico, foi observada a relação da lesão com o forame mentoniano, apresentando-se firmemente aderida ao periósteo e ao nervo mentoniano. Após o diagnóstico microscópico de neurofibroma plexiforme, foram investigados outros sinais da NF-1, entretanto, constatou-se que a lesão era solitária.

O neurofibroma, principalmente a variante plexiforme, pode ocorrer na cavidade bucal como parte da NF-1 ou NF-2. PRESCOTT; WHITE ${ }^{38}$ e RICCHARDS $^{40}$ afirmaram que para muitos patologistas a ocorrência isolada dessa lesão caracteriza uma manifestação frustrada da síndrome da neurofibromatose 1 e que lesões múltiplas podem surgir tardiamente na vida. Esses autores ressaltam a importância da investigação das neurofibromatoses, bem como a importância da proservação do paciente quando a ocorrência de uma lesão isolada na boca. 
Proposição 


\section{PROPOSIÇÃO}

A partir da análise de 66 neurofibromas localizados na região de cabeça e pescoço propusemos:

1. caracterizar estas lesões quanto aos seus aspectos clínicos e aos aspectos morfológicos, em coloração de rotina, com base na microscopia óptica;

2. avaliar a freqüência de neurofibroma isolado na pele e boca quando não associado a NF-1 e discutir suas implicações clínicas;

3. discutir as condutas clínicas e patogênese do neurofibroma, particularmente da variante plexiforme, quando de sua ocorrência isolada na boca. 
Material e Métodos 


\section{MATERIAL E MÉTODOS}

\subsection{Obtenção e seleção da amostra}

A amostra foi selecionada a partir dos neurofibromas na região de cabeça e pescoço diagnosticados no período de 1973 a 2003, pelos Serviços de Anatomia Patológica do Departamento de Estomatologia - Área de Patologia da Faculdade de Odontologia de Bauru/USP e do Instituto de Pesquisa Lauro de Souza Lima. As peças cirúrgicas foram provenientes das duas instituições citadas acima e de outras faculdades, consultórios médicos e odontológicos.

Os critérios de inclusão da amostra foram:

- diagnóstico de neurofibroma na região de cabeça e pescoço com base nos aspectos microscópicos em colorações de rotina, seguindo se basicamente a classificação descrita pela $\mathrm{OMS}^{57}$;

- disponibilidade de um corte microscópico adequado e/ou do bloco de parafina que permitia a confecção de novos cortes da lesão a ser analisada;

- disponibilidade de informações clínicas relevantes à pesquisa;

\subsection{Registro dos dados clínicos e microscópicos}

Todos os dados clínicos e microscópicos foram registrados em um formulário próprio específico para essa finalidade como pode ser visto na Figura 1. 
As informações clínicas incluíram os dados demográficos do paciente (gênero, idade, raça), a história clínica (localização, sintomatologia, diâmetro da lesão, tempo de duração, associação com síndromes) e a evolução da lesão (presença ou não de recidiva após o tratamento cirúrgico). Estas informações foram obtidas a partir das fichas clínicas que acompanham as peças cirúrgicas enviadas para exame anatomopatológico e complementadas pela análise do prontuário.

A análise microscópica das lâminas coradas em Hematoxilina e Eosina foi realizada por dois examinadores (L.S.M. e D.T.O.) para confirmação do diagnóstico e registro de algumas características como: a morfologia celular, a organização histológica do neurofibroma e a presença, distribuição e predominância celular do infiltrado inflamatório associado à lesão. Outros componentes relacionados ao epitélio de revestimento, anexos cutâneos e vascularização sanguínea, associada ou não, à lesão, também foram avaliados.

A morfologia celular predominante e a presença de corpúsculos táteis-like do tipo Wagner-Meissner-like ou Vater-Pacini-like foram registradas como presente ou ausente.

O epitélio quando presente foi classificado quanto à estratificação (simples, estratificado ou pseudo-estratificado) e a queratinização (orto ou paraqueratinizado).

O infiltrado inflamatório foi analisado quanto à sua intensidade: discreto, moderado e intenso, tipo celular predominante (polimorfonuclear ou mononuclear) e distribuição na lesão (focal ou difuso). A presença de mastócitos no interior da lesão foi classificada em discreta, moderada e intensa.

A vascularização sanguínea foi caracterizada quanto à sua intensidade como discreta, moderada e intensa, e ainda, quanto à distribuição na lesão (de permeio ou 
adjacente à lesão). A presença ou ausência de uma cápsula fibrosa circunscrevendo a lesão também foi registrada.

\subsection{Análise dos dados}

Todos os dados clínicos e microscópicos obtidos foram armazenados em uma planilha do Excel, sendo posteriomente tabulados e expressos em porcentagens.

\subsection{Registro fotográfico}

Os campos microscópicos mais representativos dos neurofibromas na região de cabeça e pescoço analisados e corados pela Hematoxilina e Eosina foram registrados a partir de um fotomicroscópio Axioskop-2 plus, marca ZEISS.

\subsection{Caso clínico}

As características clínicas de um paciente com neurofibroma isolado em boca, não associado a síndromes foram descritas e os aspectos microscópicos da lesão, diagnosticada pelo Serviço de Anatomia Patológica do Departamento de Estomatologia - Área de Patologia da Faculdade de Odontologia de Bauru/USP, detalhadamente analisados. A análise microscópica do neurofibroma foi realizada em Hematoxilina e Eosina e pela imuno-histoquímica com os seguintes anticorpos primários: S-100 (DAKO, diluição:1:800), EMA (DAKO, diluição:1:80), CD34 (DAKO, diluição:1:50) e Colágeno IV (DAKO, diluição:1:80).

A técnica imuno-histoquímica foi realizada utilizando-se cortes microscópicos de $4 \mu \mathrm{m}$ de espessura, fixados em formalina tamponada seguindo-se basicamente a técnica padrão da estreptavidina-biotina-peroxidase de acordo com o protocolo usado no Laboratório de Anatomia Patológica e Citológica do Hospital de Base de Bauru. (Anexo 1). 
FIGURA 1 - Formulário utilizado para a coleta dos dados clínicos e microscópicos dos pacientes portadores de neurofibroma na região de cabeça e pescoço

\section{FORMULÁRIO PARA COLETA DE DADOS CLÍNICOS E MICROSCÓPICOS}

"NEUROFIBROMA ISOLADO NA REGIÃO DE CABEÇA E PESCOÇO: CONSIDERAÇÕES CLÍNICAS E HISTOPATOLÓGICAS"

C.D. Luciana Sassa Marocchio; Profa. Dra. Denise Tostes Oliveira; Dr Raul Negrão Fleury

\section{DADOS CLÍNICOS}

1. $R G$ (Registro geral hospitalar):

2. Número da lâmina:

3. Idade: $\square 1.0-20$ anos $\square$ 2. 21-40 anos $\square$ 3.41-60 anos $\square$ 4. 61-80 anos

4. Gênero: $\square$ 1. Feminino $\square$ 2. Masculino

5. Raça: $\square$ 1. Branca $\square$ 2. Amarela $\square$ 3. Negra $\square$ 4. Outra

6. Diagnóstico clínico:

7. Diâmetro da lesão(cm): $\square$ 1. 0,1-1,0 $\square$ 2. 1,1-2,0 $\square$ 3. 2,1-3,0 $\square$ 4. Mais de 3,0

8. Síndrome: $\square$ 1. Sim $\square$ 2. Não $\square$ 3. Não informado/Nada consta

9. Se sim qual?

10. Outros familiares afetados $\square$ 1. Sim $\square$ 2. Não $\square$ 3. Não informado

11. Lesões: $\square$ 1. Isoladas $\quad \square$ 2. Múltiplas

12. Localização

13. Sintomas: $\square$ 1. Presente $\square$ 2. Ausente Se presente, qual?

14. Tempo de duração da lesão: $\square$ 1. Desde o nascimento $\square$ 2.Desde a infância
$\square 3 .<5$ anos
$\square 4 .>5$ anos

15. Recidiva: $\square$ 1. Sim $\square$ 2. Não $\square$ 3. Ignorado 
16. Se sim, após quanto tempo?

17. Número da lâmina

\section{DADOS MICROSCÓPICOS}

18. Epitélio: $\square$ 1. Presente $\square$ 2. Ausente

19. Tipo de epitélio: $\square$ 1. Estratificado $\square$ 2. Simples $\square$ 3. Pseudoestratificado

20. Queratinização: $\square$ 1. Ortoqueratinizado $\square$ 2. Paraqueratinizado $\square$ 3. Ausente

21. Anexos cutâneos: $\square$ 1. Ausente $\square$ 2. Presente

22. Neurofibroma (Lesão): $\square$ 1. Localizada $\square$ 2. Difusa

23. Morfologia celular predominante: $\square$ 1. Ovalado $\square$ 2. Fusiforme

24. Organização histológica: $\square$ 1.Enovelado $\square$ 2.Fasciculado $\square$ 3. Difuso

25. Tipo histológico: $\square$ 1. Plexiforme $\square$ 2. Difusob

26. Corpúsculo tátil-like: : $\square$ 1. Ausente $\square$ 2. Presente

27. Tipo do corpúsculo tátil-like: $\square$ 1.Wagner-Meissner-like $\square$ 2. Vater-Pacini-like

28. Cápsula fibrosa: $\square$ 1. Presente $\square 2$. Ausente

29. Infiltrado inflamatório: $\square$ 1. Presente $\square 2$. Ausente

30. Infiltrado inflamatório: $\square$ 1. De permeio a lesão $\square$ 2. Periférico a lesão

31. Tipo celular do infiltrado inflamatório: $\square$ 1. Mononuclear $\square$ 2. Polimorfonuclear

32. Intensidade do infiltrado inflamatório: $\square$ 1. Discreta $\square$ 2. Moderada $\square$ 3. Intensa

33. Mastócitos: $\square$ 1. Discreto $\square$ 2. Moderado $\square$ 3. Intenso

34. Vascularização sanguínea: $\square$ 1. Presente $\square 2$. Ausente

35. Vasos sanguíneos (Localização): $\square$ 1.De permeio à lesão $\square$ 2. Periférico à lesão

36. Vasos sanguíneos (Intensidade): $\square$ 1. Discreta $\square$ 2. Moderada $\square$ 3. Intensa 
Resultados 


\section{RESULTADOS}

\subsection{Características clínicas da população de estudo}

Nossa casuística revelou que os 43 pacientes com neurofibromas na região de cabeça e pescoço apresentavam uma maior freqüência dessas lesões em pele $(72,1 \%)$ do que em mucosa bucal $(27,9 \%)$ como pode ser observado na Tabela 2.

TABELA 2 - Distribuição dos neurofibromas na região de cabeça e pescoço nos 43 pacientes da amostra quanto aos critério de inclusão estabelecidos. Faculdade de Odontologia de Bauru- USP e Instituto de Pesquisa Lauro de Souza Lima, 1970 a 2003

\begin{tabular}{lcc}
\hline Distribuição Anatômica & Número de pacientes & $\mathbf{\%}$ \\
\hline Pele & 31 & 72,1 \\
Mucosa bucal & 12 & 27,9 \\
\hline Total & $\mathbf{4 3}$ & $\mathbf{1 0 0}$ \\
\hline
\end{tabular}

A análise dos dados demográficos relativos aos 43 pacientes revelou um leve predomínio pelo gênero feminino $(60,5 \%)$, enquanto o gênero masculino constituía $39,5 \%$ dos pacientes. Quanto à raça verificou-se que os neurofibromas se manifestaram predominantemente em indivíduos da raça branca $(76,8 \%)$, seguidos pela raça negra $(4,6 \%)$ e outras raças $(14,0 \%)$. Não houve nenhum representante da raça amarela em nossa amostra. Em dois pacientes $(4,6 \%)$ a informação referente à raça não foi relatada (Tabela 3). 
A idade mínima obtida na época do diagnóstico de neurofibroma na região de cabeça e pescoço foi de nove anos e a idade máxima de 86 anos. A maioria dos pacientes apresentava idade acima de 40 anos $(62,8 \%)$, os mais jovens, com até 20 anos perfaziam um total de $11,6 \%$, enquanto os que estavam em idade intermediária ( $>20$ e $<40$ anos) constituíam $25,6 \%$ da amostra. (Tabela 3).

TABELA 3 - Distribuição de freqüência dos pacientes com neurofibromas na região de cabeça e pescoço segundo os dados demográficos. Faculdade de Odontologia de Bauru/USP e Instituto de Pesquisa Lauro de Souza Lima, 1970 a 2003

\begin{tabular}{lcc}
\hline Característica & Número de pacientes & $\%$ \\
\hline Gênero & 17 & 39,5 \\
Masculino & 26 & 60,5 \\
Feminino & & \\
Raça & 33 & 76,8 \\
Branca & 2 & 4,6 \\
Negra & 0 & 0,0 \\
Amarela & 6 & 14,0 \\
Outra & 2 & 4,6 \\
Não especificado & & 11,6 \\
Faixa etária & 5 & 25,6 \\
0 a 20 anos & 11 & 62,8 \\
21 a 40 anos & 27 & $\mathbf{1 0 0}$ \\
\hline 40 anos & $\mathbf{4 3}$ & \\
\hline Total & & \\
\hline
\end{tabular}

Clinicamente, 22 pacientes $(51,2 \%)$ apresentaram uma única lesão de neurofibroma na região de cabeça e pescoço, enquanto que em $16(37,2 \%)$ pacientes 
as lesões eram múltiplas, sugerindo, nesses casos uma possível associação com a Síndrome da Neurofibromatose (Tabela 4).

Em apenas 12 casos $(28,0 \%)$ o diagnóstico da Síndrome da Neurofibromatose-1 foi confirmado, sendo que 3 pacientes $(7,0 \%)$ possuíam um familiar afetado e em 5 (11,7\%) nenhuma manifestação familiar desta síndrome foi confirmada (Tabela 4).

No diagnóstico clínico diferencial sugerido pelos profissionais, $10(23,5 \%)$ foram de neurofibroma e $7(16,2 \%)$ de Neurofibromatose-1. Outras lesões $(13,9 \%$ da amostra) como hiperplasia fibrosa inflamatória, fibroma, lipoma e carcinoma basocelular também foram incluídas como hipóteses, principalmente, naqueles pacientes com neurofibroma isolado na região de cabeça e pescoço. Para as lesões de pele, o nevo celular intradérmico foi incluído como diagnóstico diferencial em 7 pacientes $(16,2 \%)$, como pode ser observado na Tabela 4.

Como pode ser visualizado na Tabela 5, o tempo de duração dos neurofibromas relatado por 25 pacientes $(58,1 \%)$ variou desde o nascimento até lesões com mais de cinco anos. Um total de $11(25,6 \%)$ pacientes confirmaram que possuíam a lesão há mais de cinco anos, $3(7,0 \%)$ desde o nascimento e em 1 paciente $(2,3 \%)$ o neurofibroma estava presente desde a infância. Mesmo com um longo tempo de duração, os neurofibromas na região de cabeça e pescoço não apresentavam grandes dimensões, sendo a maioria $(76,7 \%)$ destes menores que $2 \mathrm{~cm}$ de diâmetro(Tabela 5). 
TABELA 4 - Distribuição de frequência dos pacientes com neurofibromas na região de cabeça e pescoço segundo o diagnóstico clínico estabelecido. Faculdade de Odontologia de Bauru/USP e Instituto de Pesquisa Lauro de Souza Lima, 1970 a 2003

\begin{tabular}{|c|c|c|}
\hline Característica & Número de pacientes & $\%$ \\
\hline \multicolumn{3}{|l|}{ Lesões } \\
\hline Múltiplas & 16 & 37,2 \\
\hline Única & 22 & 51,2 \\
\hline Não especificado & 5 & 11,6 \\
\hline \multicolumn{3}{|l|}{ Diagnóstico clínico } \\
\hline Neurofibroma & 10 & 23,5 \\
\hline Neurofibromatose & 7 & 16,2 \\
\hline Nevo celular intradérmico & 7 & 16,2 \\
\hline Outras & 6 & 13,9 \\
\hline Não especificado & 13 & 30,2 \\
\hline \multicolumn{3}{|l|}{ Associação com Síndromes } \\
\hline Presente & 12 & 28,0 \\
\hline Ausente & 16 & 37,2 \\
\hline Não especificado & 15 & 34,8 \\
\hline \multicolumn{3}{|c|}{ Síndrome e Familiares afetados* } \\
\hline Ausente & 5 & 11,7 \\
\hline Presente & 3 & 7,0 \\
\hline Não especificado & 4 & 9,3 \\
\hline Total & 43 & 100 \\
\hline
\end{tabular}

Clinicamente, nenhum sintoma foi associado ao neurofibroma em 30,2\% dos pacientes e apenas um paciente $(2,3 \%)$ relatou a ocorrência de dor e prurido (Tabela 5).

Todos os pacientes com neurofibroma de cabeça e pescoço foram submetidos à exérese total da lesão. Em alguns pacientes com lesões múltiplas, o tratamento 
cirúrgico foi realizado em várias etapas, ressaltando-se que, 2 pacientes com NF-1 se submeteram a remoção de quatro neurofibromas cada um na região de cabeça e pescoço. Catorze pacientes foram acompanhados pós-cirurgicamente por um período de 3 a 230 meses e destes, 10 eram portadores da NF-1 não sendo registrado nenhum caso de recorrência da lesão, como pode ser visualizado na Tabela 5.

TABELA 5 - Distribuição de freqüência dos pacientes com neurofibromas na região de cabeça e pescoço segundo a história clínica. Faculdade de Odontologia de Bauru/USP e Instituto de Pesquisa Lauro de Souza Lima, 1970 a 2003

\begin{tabular}{lcc}
\hline Característica & Número de pacientes & $\%$ \\
\hline Tempo de duração & 3 & 7,0 \\
Desde o nascimento & 1 & 2,3 \\
Desde a infância & 10 & 23,2 \\
$<$ 5anos & 11 & 25,6 \\
$>$ 5anos & 18 & 41,9 \\
Não especificada & & \\
Tamanho da lesão & 33 & 76,7 \\
$<2$ cm & 6 & 14,0 \\
$>$ 2cm & 4 & 9,3 \\
Não especificado & & \\
Sintomas clínicos & 25 & 58,2 \\
Ausente & 1 & 2,3 \\
Presente & 17 & 39,5 \\
Não especificado & & $\mathbf{1 0 0}$ \\
Recorrência & 14 & 32,6 \\
Ausente & 0 & 0,0 \\
Presente & 29 & \\
Não especificado & & \\
\hline Total & & \\
\hline
\end{tabular}


Como pode ser observado na Tabela 6 , a maioria dos neurofibromas da região de cabeça e pescoço $(81,8 \%)$ eram lesões cutâneas localizadas, principalmente, na região da face $(65,2 \%)$, do pescoço $(13,6 \%)$ e do couro cabeludo $(3,0 \%)$. Na mucosa bucal, 5 neurofibromas $(7,6 \%)$ encontravam-se na região de rebordo alveolar e gengiva e $2(3,1 \%)$ em língua. Uma lesão (1,5\%) mandibular encontrava-se aderida ao periósteo. Regiões como mucosa jugal, lábio superior e assoalho bucal também foram afetadas pelos neurofibromas da região de cabeça e pescoço (Tabela 6).

TABELA 6 - Distribuição de freqüência dos neurofibromas na região de cabeça e pescoço segundo a localização. Faculdade de Odontologia de Bauru/USP e Instituto de Pesquisa Lauro de Souza Lima, 1970 a 2003

\begin{tabular}{lcc}
\hline Localização & Número de lesões & \% \\
\hline Pele & 43 & 65,2 \\
Face & 9 & 13,6 \\
Pescoço & 2 & 3,0 \\
Couro cabeludo & & \\
Mucosa bucal & 5 & 7,6 \\
Gengiva/rebordo alveolar & 2 & 3,1 \\
Língua & 1 & 1,5 \\
Mucosa jugal & 1 & 1,5 \\
Região Mentoniana & 1 & 1,5 \\
Soalho bucal & 1 & 1,5 \\
Região parasinfisária (mandíbula). & 1 & 1,5 \\
Lábio superior & $\mathbf{6 6}$ & $\mathbf{1 0 0}$ \\
\hline Total & & \\
\hline
\end{tabular}




\subsection{Análise microscópica}

Um total de 66 neurofibromas da região de cabeça e pescoço, corados em Hematoxilina e Eosina, de 43 indivíduos foi microscopicamente avaliado. Dos 66 neurofibromas analisados, 27 lesões (40,9\%) ocorreram em pacientes com NF-1. Todas as lesões removidas de um mesmo paciente em diferentes períodos de tempo com diagnóstico de neurofibroma foram incluídas nesta análise.

A arquitetura microscópica dos neurofibromas analisados foi característica, com células fusiformes ou ovaladas distribuídas em um estroma colagênico de densidade variável, às vezes, formando enovelados semelhantes a feixes nervosos cortados transversalmente (Figuras 2, 3 e 5). Algumas lesões $(9,1 \%)$ apresentavam um padrão histológico mais organizado no qual as fibras colágenas dispostas em uma mesma direção, se agrupavam em feixes mais espessos (Tabela 7 e Figura 2B).

A presença ocasional de corpúsculos táteis-like também foi observada nos neurofibromas cutâneos e mucosos (Figura 3B e 4B).

Com base na classificação microscópica utilizada observou-se que os neurofibromas do tipo difuso (Figura $2 \mathrm{~A}$ e $3 \mathrm{~A}$ ) foram mais freqüentes $(97,0 \%)$ se comparado ao tipo plexiforme $(3,0 \%)$.

Os dois neurofibromas plexiformes (16,6\% dos casos de boca), ambos localizados na mucosa bucal, apresentavam a típica organização histológica em enovelado, semelhante a feixes nervosos cortados transversalmente circunscritos, porém expandidos, por um tecido conjuntivo pouco denso, lembrando o perineuro (Figura 7). Em seu interior observaram-se células fusiformes com citoplasma pouco visível, algumas dispostas concentricamente em um conjuntivo frouxamente organizado. 
A presença do epitélio de revestimento estratificado pavimentoso queratinizado, sobrejacente às lesões localizadas na região submucosa ou dérmica, foi observada em 55 espécimes $(83,3 \%)$ sendo a maior parte constituída superficialmente por ortoqueratina $(75,7 \%)$ e apenas $4(6,1 \%)$ por paraqueratina. Em um único neurofibroma $(1,5 \%)$ a presença de orto e paraqueratina foi encontrada simultaneamente no epitélio. Onze lesões $(16,7 \%)$ não apresentavam epitélio de revestimento.

Os neurofibromas com menores diâmetros apresentavam-se mais localizados, com limites claramente definidos na derme ou na submucosa (Tabela 7). Por outro lado, as lesões maiores eram difusamente distribuídas, algumas com localização mais profunda na região cutânea ou mucosa, circunscrevendo feixes de fibras musculares estriadas esqueléticas e vasos sanguíneos de maior calibre. Os anexos cutâneos, como folículos pilosos, glândulas sebáceas e sudoríparas também encontravam-se circundados pelos neurofibromas difusos.

Perifericamente, algumas lesões localizadas apresentavam um tecido conjuntivo comprimido com aspecto capsular, entretanto, este tecido era irregular e descontínuo não constituindo uma cápsula fibrosa verdadeira (Figura 3).

A morfologia das células tumorais predominantemente observada foi a fusiforme (86,3\%), caracterizada principalmente pelo o núcleo alongado e ondulado, e citoplasma escasso geralmente confundindo-se com as fibras colágenas do estroma (Figura 5). Células com morfologia arredondada e nucléolo freqüentemente evidente também foram notadas $(13,7 \%)$ sempre imiscuídas com as fusiformes, no entanto nunca perfazendo a maioria das células tumorais. 
Pequenos feixes nervosos remanescentes também foram identificados de permeio a lesão (Figura 5B).

A presença de infiltrado inflamatório crônico predominantemente linfocitário, discreto ou moderado, focal e perivascular, foi observada de permeio às células do neurofibroma em $44 \%$ dos espécimes (Tabela 7). A ausência de infiltrado inflamatório associado às células tumorais foi registrada na maioria $(56,1 \%)$ dos neurofibromas da região de cabeça e pescoço (Tabela 7 e Figura 5B).

Uma moderada ou intensa vascularização sanguínea (Tabela 7) foi observada tanto perifericamente $(6,1 \%)$ quanto no interior da lesão $(30,3 \%)$, de permeio às células tumorais como pode ser visualizado na Figura 6A. Constatou-se também nesses espécimes, intenso número de mastócitos (Tabela 7), alguns degranulados, localizados freqüentemente na região perivascular, tanto nos neurofibromas cutâneos como naqueles localizados na mucosa bucal (Figura 6B). 
TABELA 7 - Distribuição de freqüência dos neurofibromas na região de cabeça e pescoço segundo as características microscópicas avaliadas. Faculdade de Odontologia de Bauru/USP e Instituto de Pesquisa Lauro de Souza Lima, 1970 a 2003

\begin{tabular}{|c|c|c|}
\hline Característica & Número de lâminas & $\%$ \\
\hline \multicolumn{3}{|l|}{ Classificação microscópica } \\
\hline Neurofibroma Plexiforme & 2 & 3,0 \\
\hline Neurofibroma Difuso & 64 & 97,0 \\
\hline \multicolumn{3}{|l|}{ Organização Histológica } \\
\hline Enovelada & 2 & 3,0 \\
\hline Fasciculada & 9 & 13,6 \\
\hline Difusa & 55 & 83,4 \\
\hline \multicolumn{3}{|l|}{ Feixes nervosos } \\
\hline Presentes & 41 & 62,1 \\
\hline Ausentes & 25 & 37,9 \\
\hline \multicolumn{3}{|l|}{ Distribuição tecidual } \\
\hline Localizada & 53 & 80,3 \\
\hline Difusa & 13 & 19,7 \\
\hline \multicolumn{3}{|c|}{ Infiltrado inflamatório crônico } \\
\hline Presente & 29 & 44,0 \\
\hline Ausente & 37 & 56,0 \\
\hline \multicolumn{3}{|l|}{ Mastócitos } \\
\hline Presente & 40 & 60,6 \\
\hline Ausente & 26 & 39,4 \\
\hline \multicolumn{3}{|l|}{ Vascularização sanguínea } \\
\hline De permeio à lesão & 20 & 30,3 \\
\hline Periférica à lesão & 4 & 6,1 \\
\hline Ambos & 42 & 63,3 \\
\hline \multicolumn{3}{|c|}{ Intensidade da vascularização } \\
\hline Discreta & 10 & 15,2 \\
\hline Moderada & 38 & 57,5 \\
\hline Intensa & 18 & 27,3 \\
\hline Total & 66 & 100 \\
\hline
\end{tabular}



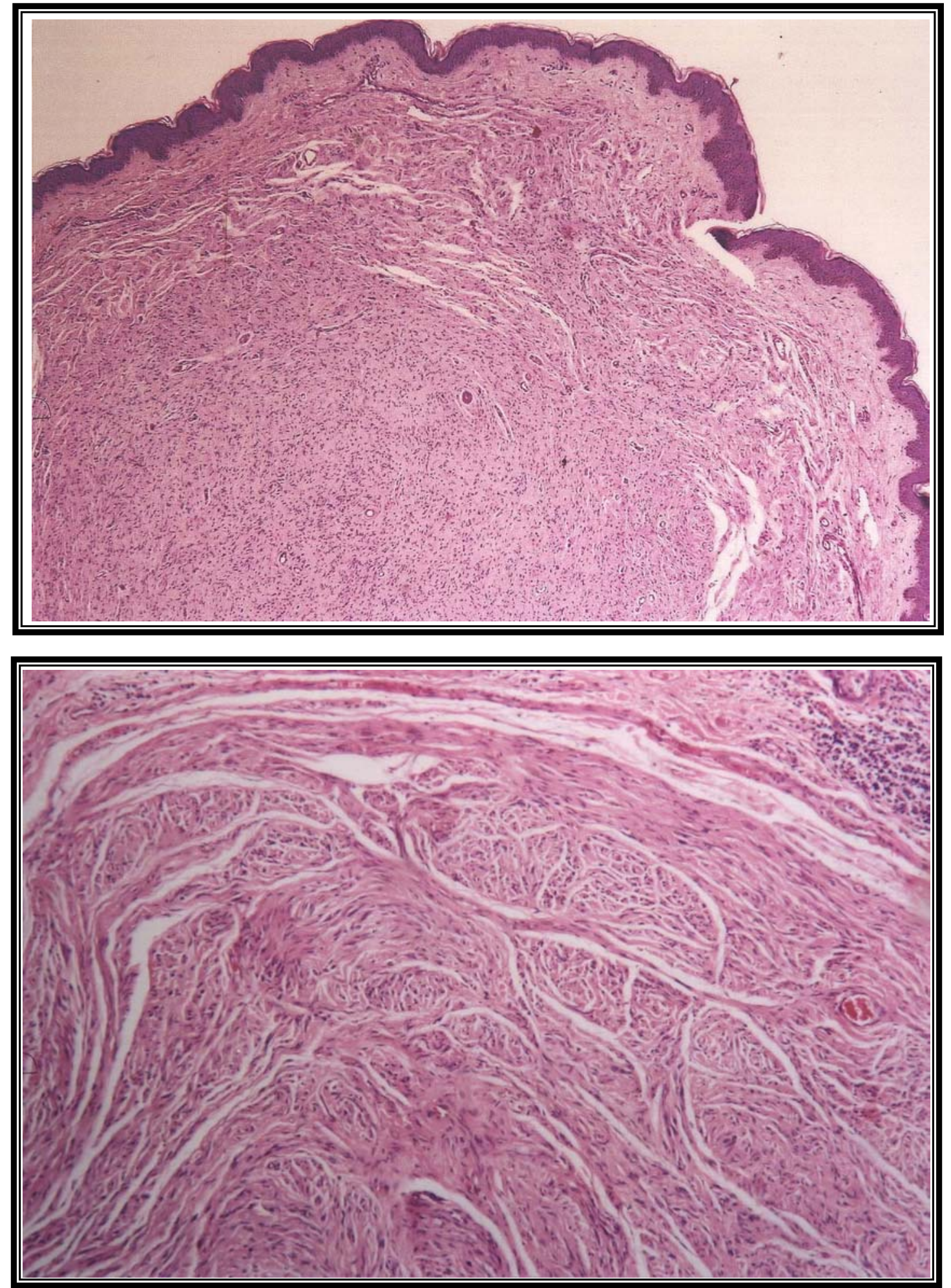

FIGURA 2 Neurofibroma localizado na derme com organização microscópica difusa (A) ou em feixes (B). (H.E.; aumento original: $\mathrm{A}=50 \mathrm{x} ; \mathrm{B}=100 \mathrm{x}$ ) 

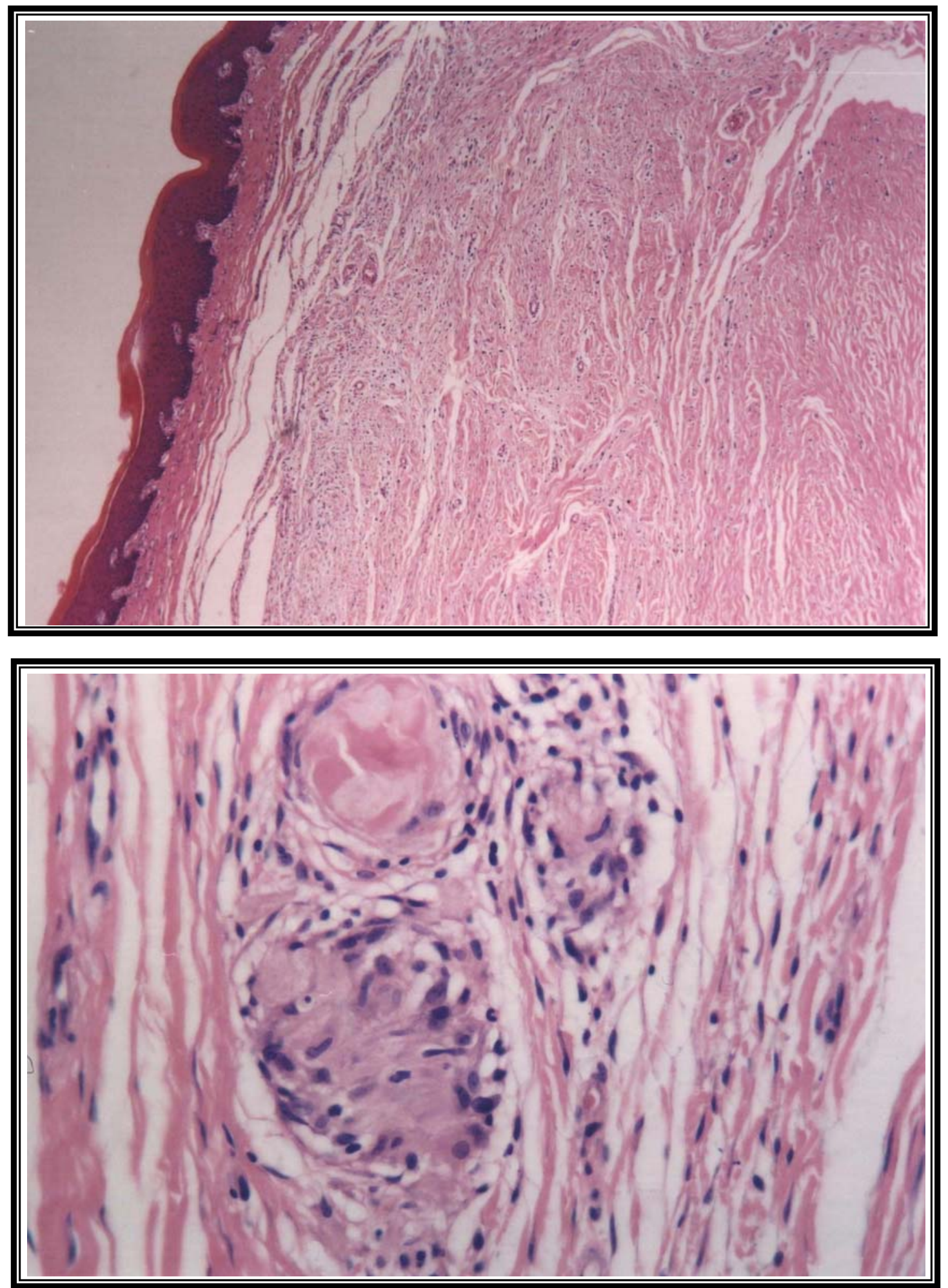

FIGURA 3 Neurofibroma difuso na submucosa com nítida separação entre a lesão e a lâmina própria (A). Em B, presença de corpúsculos de Wagner Meisnner-like. (H.E.; aumento original: $\mathrm{A}=50 \mathrm{x} ; \mathrm{B}=400 \mathrm{x}$ ) 

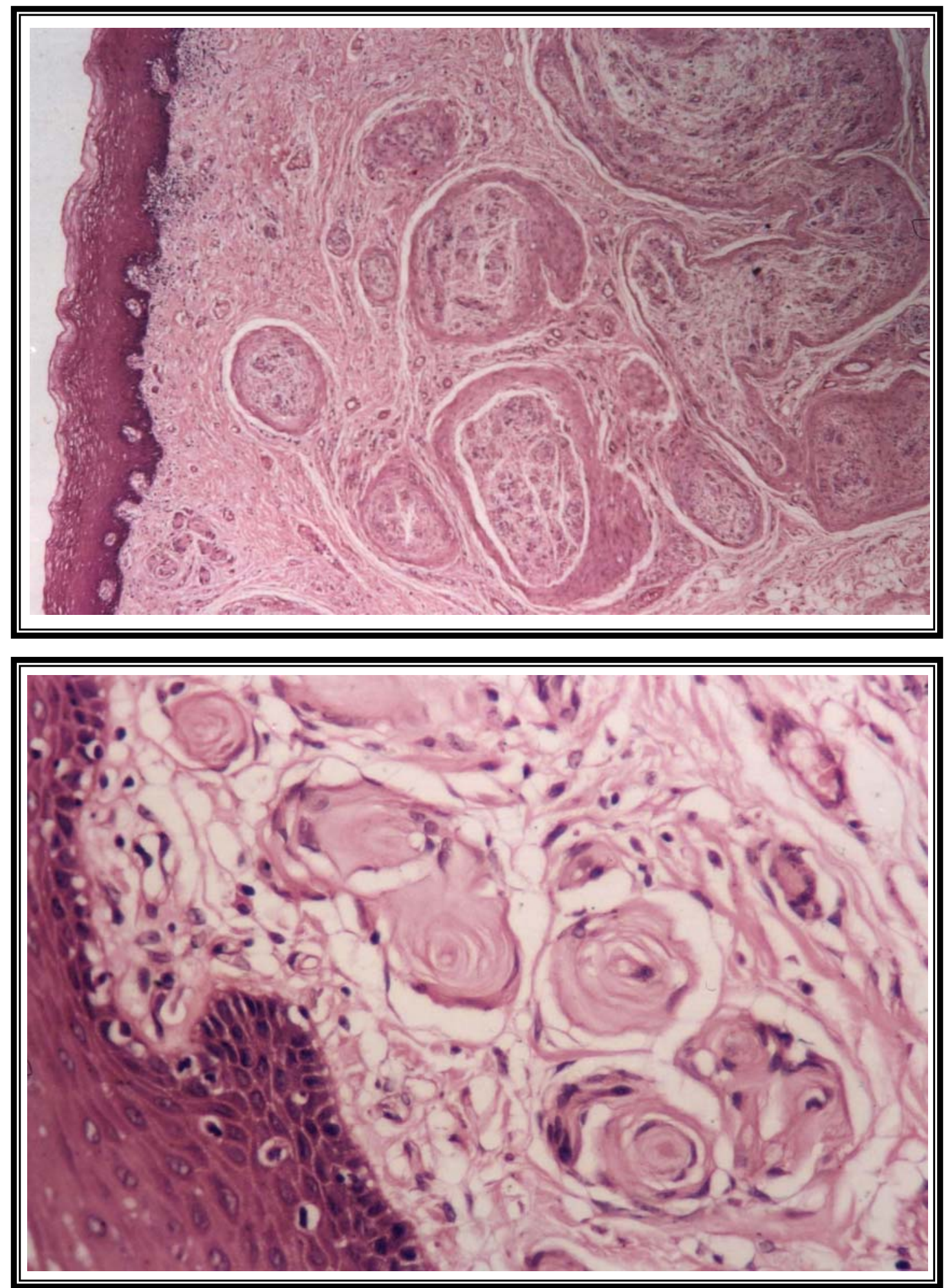

FIGURA 4 Neurofibroma plexiforme na mucosa bucal com organização característica de feixes nervosos cortados transversalmente (A). Em B, observar a presença de corpúsculos Vater-Pacini like. (H.E.; aumento original: $\mathrm{A}=100 \mathrm{x} ; \mathrm{B}=400 \mathrm{x}$ ) 

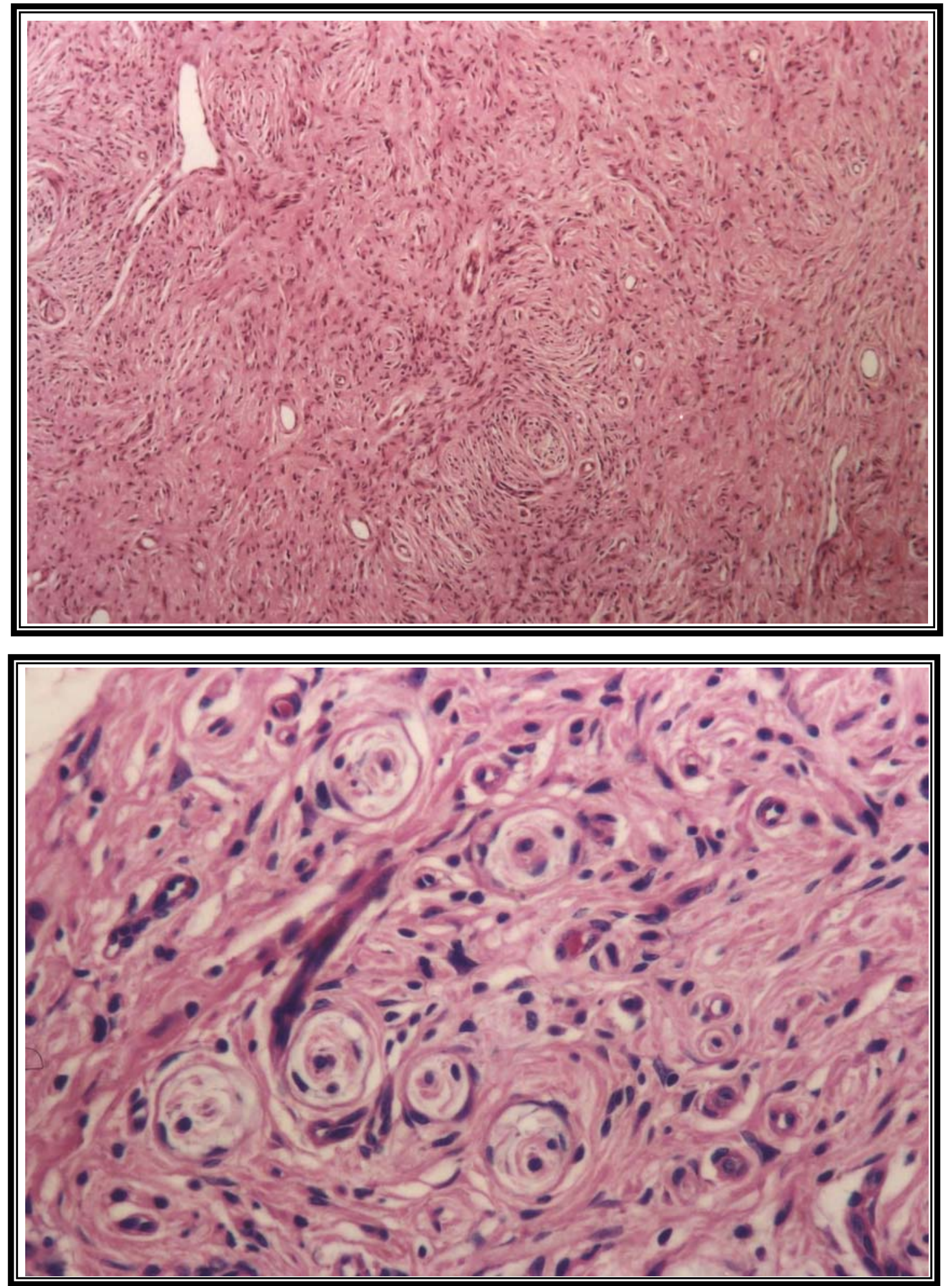

FIGURA 5 Observar a distribuição das células fusiformes no interior de um neurofibroma difuso (A) e a presença de pequenos feixes nervosos cortados transversalmente (B). (H.E.; aumento original: $A=100 x ; B=400 x$ ) 

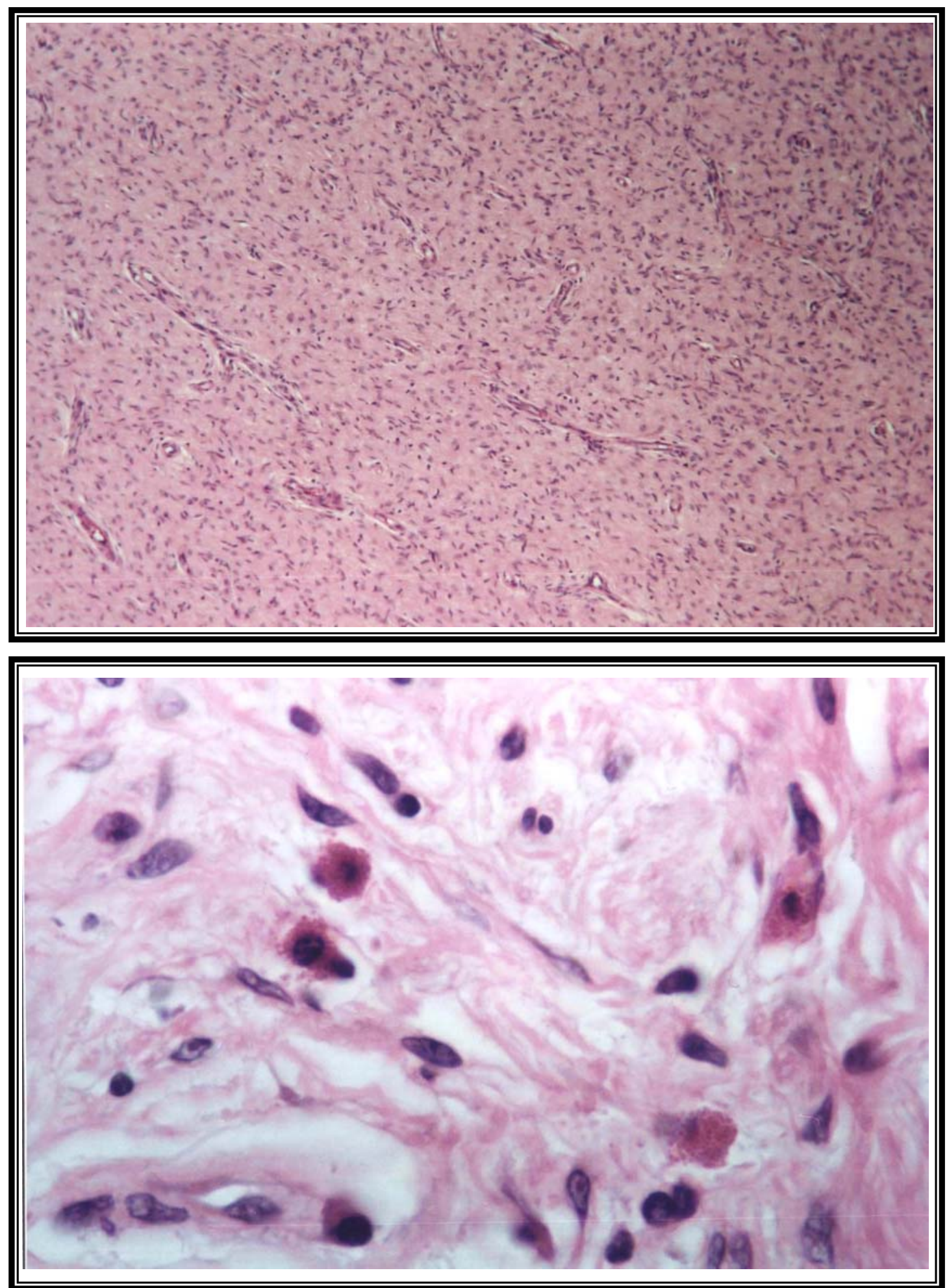

FIGURA 6 Além da intensa vascularização sanguínea (A), diversos mastócitos foram observados nos neurofibromas da região de cabeça e pescoço (B). (H.E.; aumento original: $\mathrm{A}=100 \mathrm{x} ; \mathrm{B}=1000 \mathrm{x}$ ) 


\subsection{Caso clínico}

Paciente do gênero feminino, 24 anos, leucoderma, procurou a Faculdade de Odontologia de Bauru-USP, queixando-se de nódulo localizado em mucosa jugal direita, assintomático e com pouco tempo de evolução. Ao exame clínico intrabucal a lesão apresentou coloração normal, consistência flácida, próximo a linha de oclusão dentária. O diagnóstico clínico foi de hiperplasia fibrosa inflamatória. Foi realizada a excisão cirúrgica da lesão sob anestesia local, sendo a biópsia excisional encaminhada para exame anatomopatológico no Laboratório de Anatomia Patológica da Faculdade de Odontologia de Bauru-USP.

A peça cirúrgica apresentou-se como um fragmento de tecido mole, consistência elástica, superfície ora lisa, ora irregular, coloração acastanhada, medindo no seu maior diâmetro $1,8 \times 1,1 \mathrm{~cm}$.

Microscopicamente observou-se, em coloração de rotina, na região submucosa, feixes nervosos expandidos e cortados transversalmente, contendo células fusiformes e arredondadas dispostas de permeio a um estroma mixóide contendo delicadas fibras colágenas com organização capsular (FIGURA 7 e 8A). Notou-se ainda, a presença de corpúsculos táteis-like próximo a região subepitelial (FIGURA 8B) bem como, a presença de alguns mastócitos. Sobrejacente a lesão observou-se mucosa bucal constituída por epitélio estratificado pavimentoso paraqueratinizado hiperplásico. A imuno-histoquímica foi realizada no Laboratório de Anatomia Patológica e Citopatologia do Hospital de Base de Bauru, utilizando-se a técnica padrão da estreptavidina-biotina-peroxidase para os seguintes anticorpos: S-100, EMA, colágeno tipo IV e CD34. 
A imunorreatividade a proteína S-100 foi observada na maioria das células do neurofibroma plexiforme, bem como nos corpúsculos táteis-like (FIGURA 9). A presença de células imunopositivas para o EMA foi detectada, principalmente, na região que circundava os enovelados nervosos (FIGURA 10A). A positividade ao colágeno do tipo IV foi encontrada tanto na região pericelular de algumas células da lesão como no tecido conjuntivo de permeio aos feixes nervosos (FIGURA 10B). A marcante imunorreatividade das células fibroblásticas ao anticorpo CD34 foi observada no interior e na periferia dos feixes nervosos expandidos que compunham o neurofibroma plexiforme (FIGURA 11). O diagnóstico microscópico estabelecido foi neurofibroma plexiforme.

Sendo a presença de um único neurofibroma plexiforme um dos sinais da síndrome da NF-1, a paciente e seu descendentes (dois filhos) foram submetidos a avaliações dermatológica e oftálmica. Nas avaliações dermatológicas não foram encontradas manchas café-com-leite, sardas axilares ou inguinais e/ou neuromas mucosos. Ao exame oftamológico não se observou presença de nódulos de Lisch. A paciente foi também submetida à análise radiográfica para averiguação de alterações em ossos longos, não sendo encontrada nenhuma anormalidade.

Nenhuma associação entre o neurofibroma plexiforme bucal e a síndrome da NF-1 foi estabelecida, sugerindo se tratar de uma lesão solitária de origem neural envolvendo fibras nervosas periféricas bucais.

A paciente e seus descendentes vêm sendo proservados por três anos e na última consulta realizada em março de 2004, nenhuma alteração na pele ou mucosa bucal foi observada. 

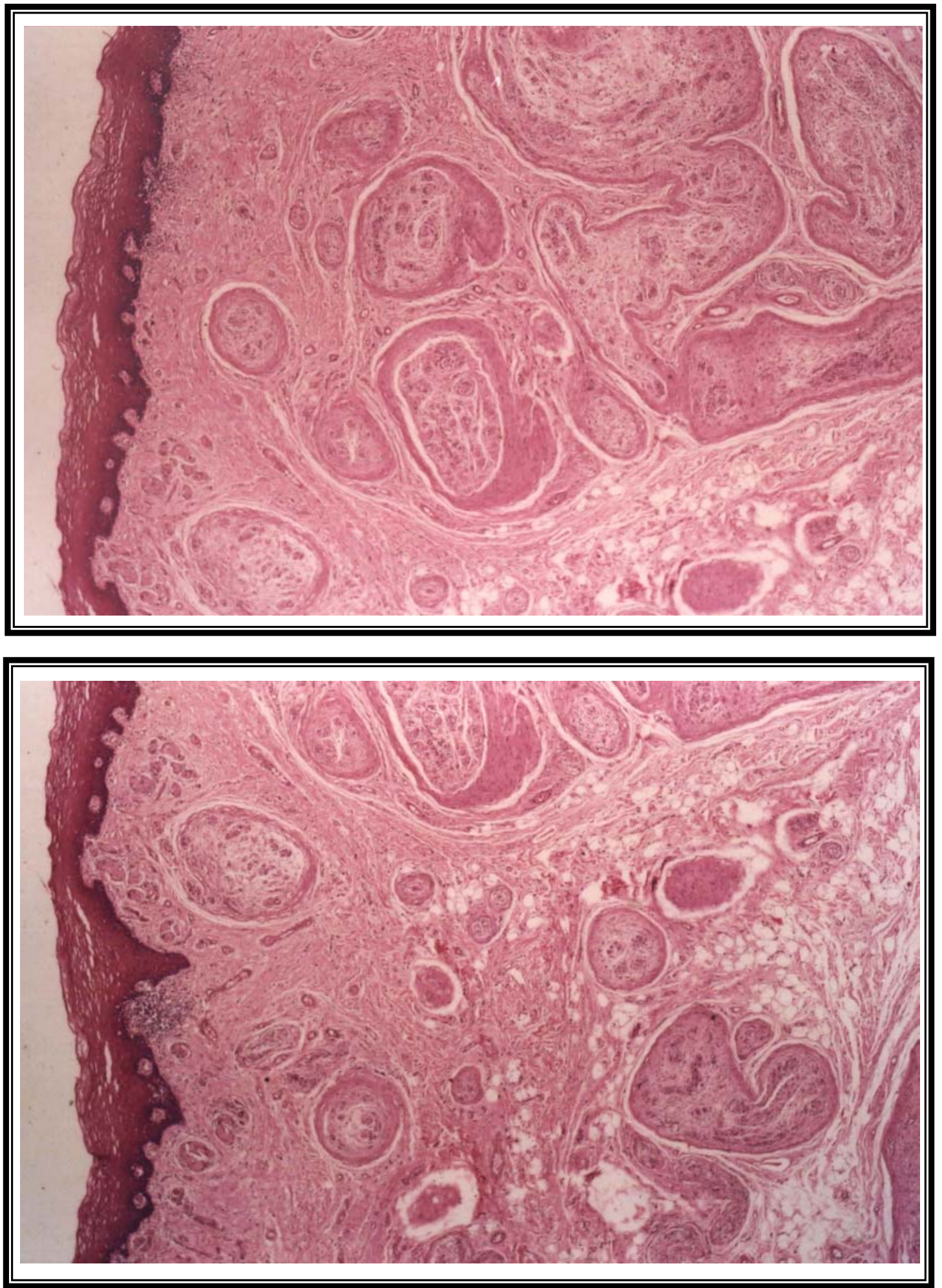

FIGURA 7 Neurofibroma plexiforme localizado na mucosa bucal com o arranjo histológico de feixes nervosos expandidos dispostos no estroma conjuntivo frouxo. (H.E.; aumento original: A e B=128x) 

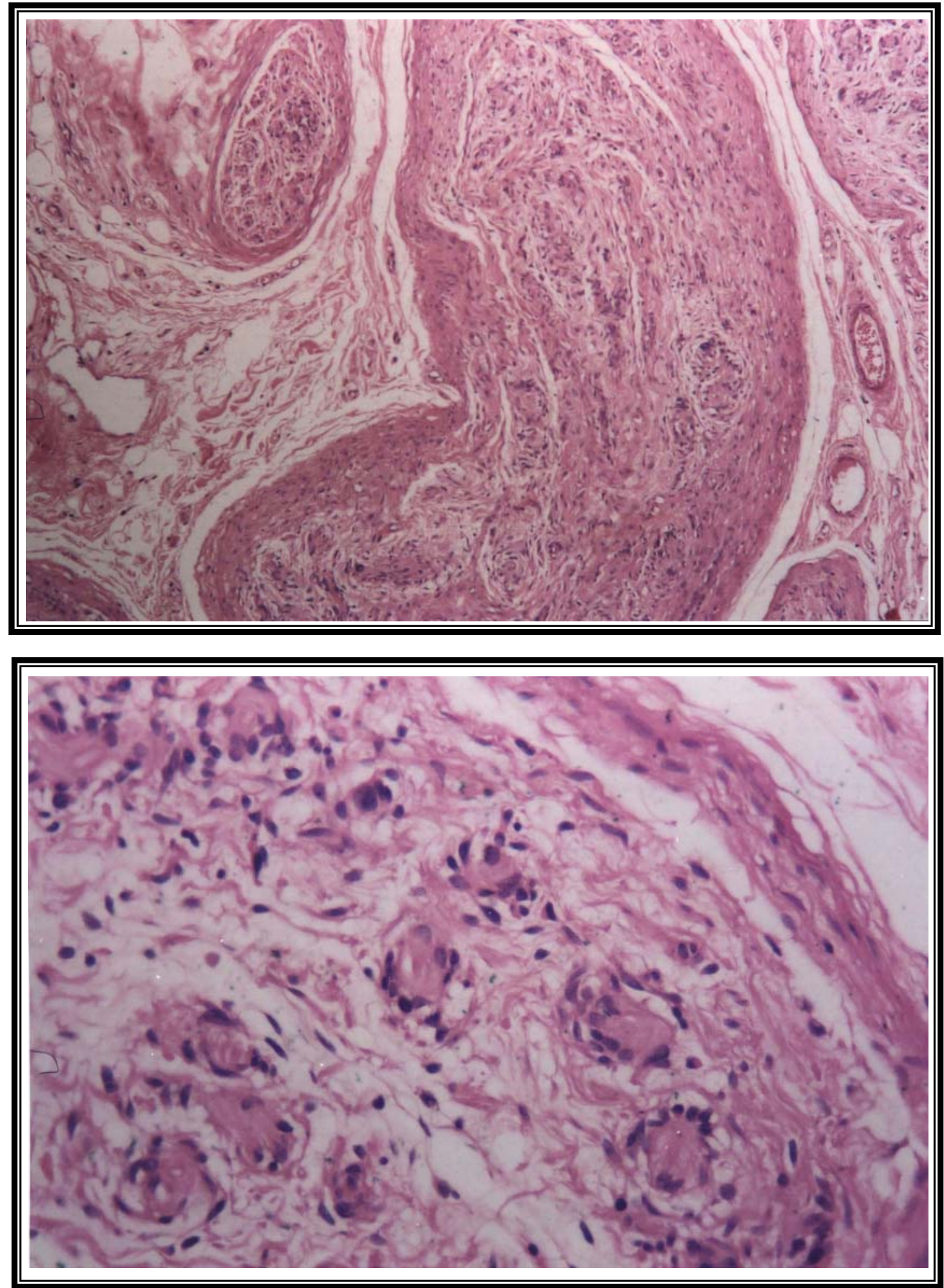

FIGURA 8 Observar a disposição celular no neurofibroma plexiforme (A) e em B, presença de corpúsculos semelhantes aos de Wagner-Meissner no interior do feixe nervoso expandido. (H.E.; aumento original: $\mathrm{A}=100 \mathrm{x} ; \mathrm{B}=400 \mathrm{x}$ ) 

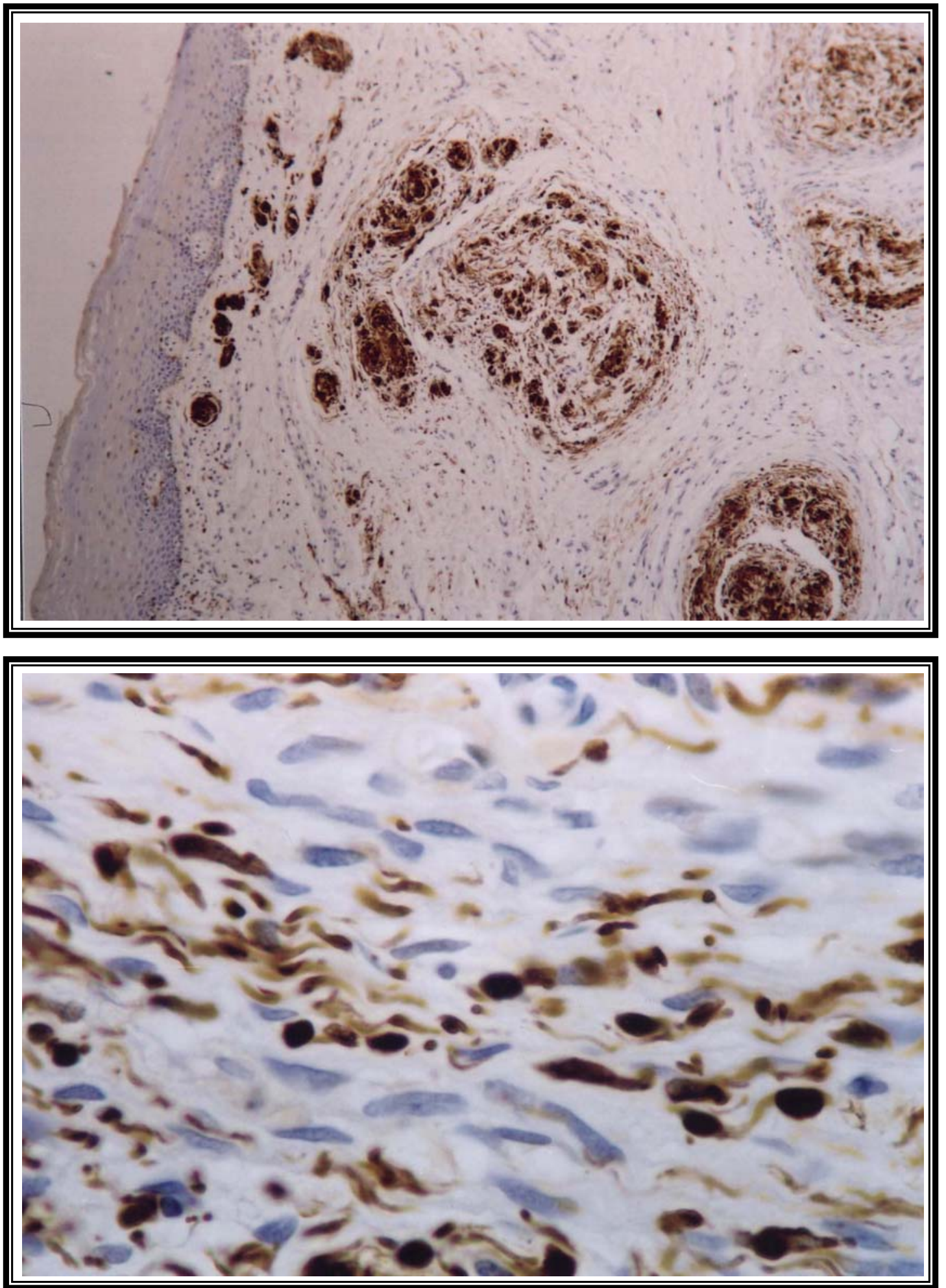

FIGURA 9 Imunomarcação da proteína S-100 no neurofibroma plexiforme (A). Em B, detalhe de algumas células imunopositivas a este anticorpo. (Imunohistoquímica: S-100; aumento original: $\mathrm{A}=50 \mathrm{x} ; \mathrm{B}=1000 \mathrm{x}$ ) 

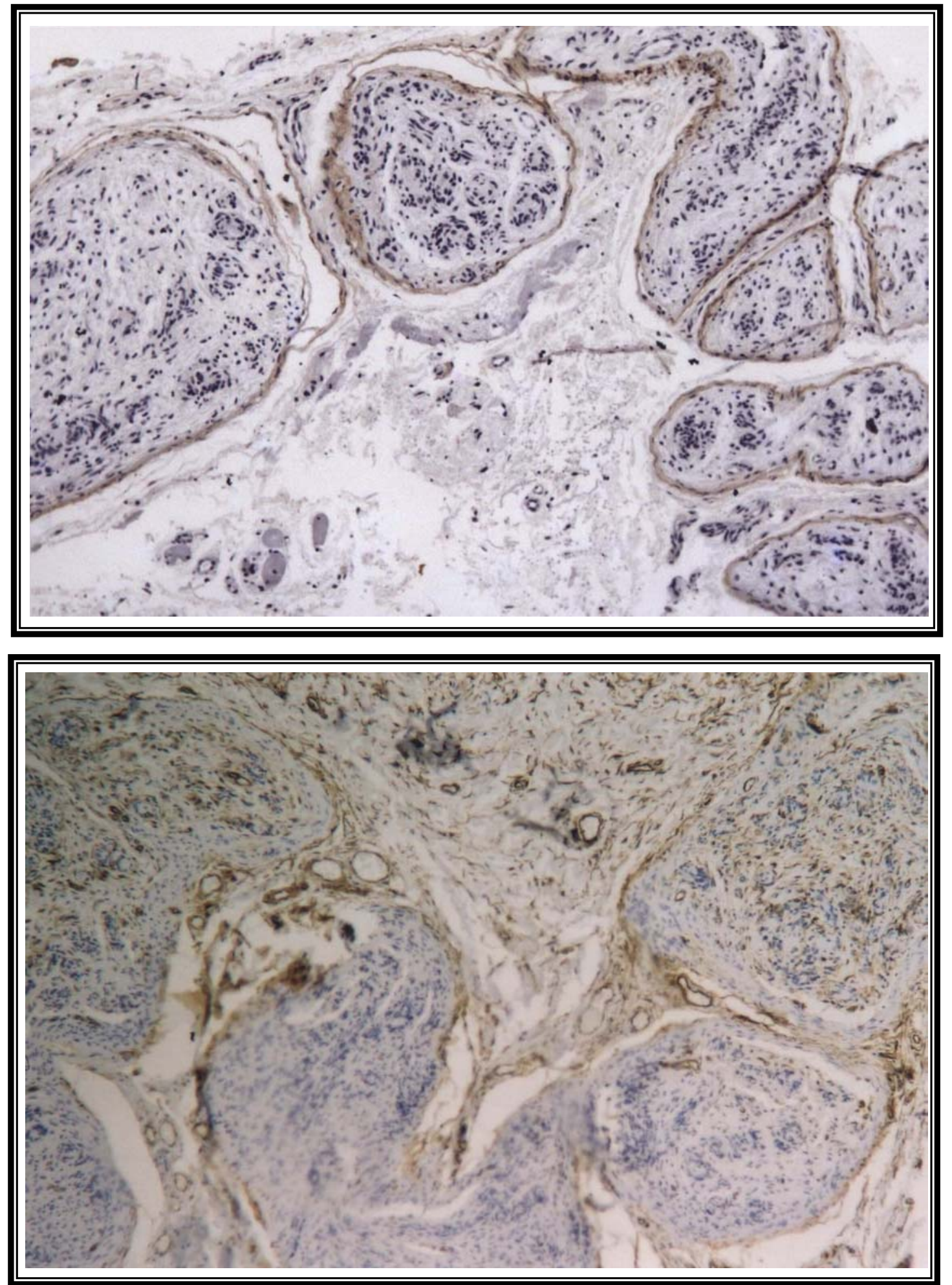

FIGURA 10 Imunomarcação para o EMA (A) e colágeno IV (B) no neurofibroma plexiforme. (Imuno-histoquímica: EMA e colágeno IV, aumento original: A e $\mathrm{B}=100 \mathrm{x})$ 

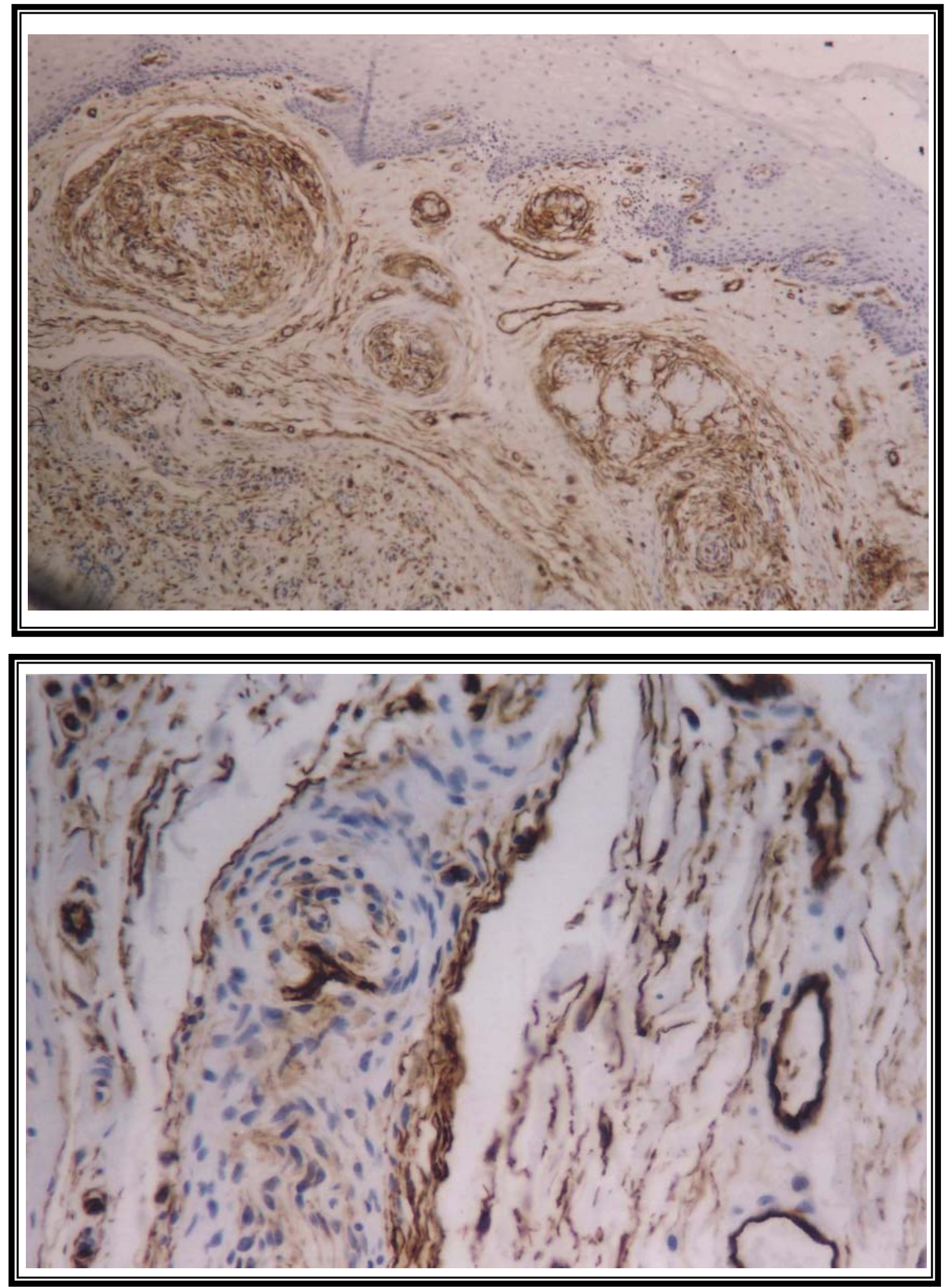

FIGURA 11 Imunomarcação da proteína CD34 com marcante imunopositividade das células fibroblásticas. (Imuno-histoquímica: CD34, aumento original: $\mathrm{A}=$ $50 \mathrm{x} ; \mathrm{B}=400 \mathrm{x})$ 
Discussão 


\section{DISCUSSÃO}

Os termos neurofibroma e schwanoma foram utilizados como sinônimos no passado, compreendendo um grupo denominado de lesões benignas da bainha neural. No entanto, com o desenvolvimento técnico e científico, essas duas lesões foram caracterizadas como entidades patológicas distintas com base, principalmente, nas diferenças clínicas, microscópicas e genéticas (Figura1) ${ }^{43}$. Atualmente, a diferenciação entre essas duas lesões de origem neural tornou-se importante não somente para a confirmação da presença ou ausência de uma síndrome, mas também para a excluir a possibilidade de tumores malignos neurais.

A concepção desse trabalho se originou quando da análise microscópica de uma peça cirúrgica de lesão em mucosa bucal com diagnóstico microscópico de neurofibroma plexiforme. Após investigação clínica, constatou-se que a paciente e seus dois descendentes não apresentavam nenhum sinal das síndromes da neurofibromatoses, suscitando muitos questionamentos, entre eles:

- qual a freqüência do neurofibroma isolado na região de cabeça e pescoço, particularmente na mucosa bucal, quando não associado à NF-1?

- teria o neurofibroma isolado uma patogênese e uma evolução clínica diferente daquelas lesões que se manifestam como parte de uma síndrome neuroectodérmica? 
- qual a conduta clínica a ser adotada quando do diagnóstico microscópico de um neurofibroma plexiforme?

Com relação à frequência dos neurofibromas da região de cabeça e pescoço um maior número de indivíduos com lesões cutâneas (72,1\%) foi observada comparativamente à mucosa bucal $(27,9 \%)$ como pode ser visualizado na Tabela 2 . Em apenas dois pacientes $(16,6 \%)$, de um total de 12 com NF-1 clinicamente comprovados, foram diagnosticados neurofibromas na boca, sendo um em rebordo alveolar e outro em língua. Essa frequência de neurofibromas bucais em pacientes com NF-1 foi maior quando comparada àquela de 4 a $7 \%$ referida por GORLIN et al. ${ }^{15}$. Embora nossa casuística seja pequena esses resultados reforçam a importância de uma avaliação intrabucal mais acurada quando da presença de neurofibromas cutâneos múltiplos ou da confirmação da síndrome da NF-1.

Clinicamente observou-se uma maior predileção pelo gênero feminino, raça branca e uma predominância para pacientes com idade acima de 40 anos, como pode ser visualizado na Tabela 3. Embora autores como, WEISS; GOLDBLUM ${ }^{56}$, SKOUTERIS; SOTEREANOS ${ }^{48}$ e WEBER; MONTANDON; ROBSON ${ }^{54}$ afirmem que os neurofibromas não apresentam predileção por gênero, nossos resultados confirmam aqueles encontrados por CHERRICK; EVERSOLE ${ }^{8}$ nos quais o gênero feminino foi mais freqüentemente afetado pela lesão. Com relação à raça, como a maioria da amostra era constituída por indivíduos da raça branca, já era esperado uma maior freqüência de neurofibromas em leucodermas.

Os neurofibromas de nossa casuística, na sua grande maioria, apresentavamse como lesões únicas ou múltiplas, superficiais, de pequenas dimensões com 
ausência de qualquer sintomatologia clínica. Em 25,6\% dos pacientes da amostra o tempo de duração das lesões era maior que cinco anos (Tabela 5) e na maioria $(62,8 \%)$ o diagnóstico de neurofibroma foi estabelecido em indivíduos com mais de 40 anos. Esse comportamento clínico benigno caracterizado por um crescimento lento e ausência de sintomatologia, como observado em nossa casuística, retarda a procura pelo tratamento e contribui para o diagnóstico tardio da lesão geralmente realizado na idade adulta(Tabela 3$)$.

Mais de 50\% dos pacientes apresentavam um único neurofibroma e 37,2\% possuíam lesões múltiplas na região de cabeça e pescoço (Tabela 4), sendo este um dos critérios estabelecidos pela conferência sobre neurofibromatose (Consensus Development Conference on Neurofibromatosis), realizada em 1988 pelo National Institutes of Health em Bethesda-USA ${ }^{29}$ para o diagnóstico da NF-1. Em $28 \%$ de nossa amostra a NF-1 foi confirmada e em 34,8\% a associação com a síndrome não pode ser estabelecida pela análise do prontuário do paciente (Tabela 4). Dos 12 pacientes com NF-1 apenas três possuíam familiares comprovadamente afetados por esta síndrome, em cinco indivíduos essa relação foi negativa e nos quatro restantes não foi estabelecida. Esses resultados exemplificam a variabilidade de manifestação clínica da NF-1 pois mesmo com padrão de herança autossômica dominante, aproximadamente 50\% dos indivíduos com NF-1 não apresentam história familiar da doença $a^{23,33,41,42,56}$.

Os neurofibromas podem também estar associados à NF-2, uma variante rara que apresenta alteração estrutural no braço curto do cromossomo 22 e com maior comprometimento do sistema nervoso central. Os schwanomas, mais do que os 
neurofibromas, são as lesões mais freqüentemente associadas à NF-2 $23,29,41,43$. Nenhum dos pacientes com neurofibroma de nossa casuística apresentou NF-2.

As hipóteses de diagnóstico clínico para os neurofibromas periféricos cutâneos e mucosos, isolados, em nossa amostra incluíram, quase sempre, lesões como nevo celular intradérmico, lipoma, fibroma e hiperplasia fibrosa inflamatória (Tabela 4) reforçando os sinais clínicos característicos de benignidade.

Outro aspecto que reflete a evolução clínica favorável dos neurofibromas refere-se à sua baixa taxa de recorrência após tratamento cirúrgico ${ }^{5,6,30}$. As lesões com maiores dimensões localizadas em região de difícil acesso cirúrgico, geralmente associadas a NF-1, possuem uma maior taxa de recorrência ${ }^{28,43}$. Em nossa amostra, constituída essencialmente por neurofibromas pequenos e superficiais, dos 14 pacientes $(32,6 \%)$ que foram proservados por um período de 3-230 meses, sendo 10 portadores de NF-1, nenhuma recorrência da lesão foi observada após o tratamento cirúrgico (Tabela 5).

Embora existam poucas informações sobre a real freqüência de neurofibromas isolado ou associado à síndrome da neurofibromatose na mucosa bucal e nos ossos maxilares ${ }^{40}$, onde alguns poucos casos clínicos foram relatados $^{1,2,5,9,27,37,38,45,46,47,48,51,50}$ autores como CHERRICK; EVESOLE ${ }^{8}$; NEVILLE et $\mathrm{al}^{30}$; RICHARDS ${ }^{40}$; SHACK, REILLEY; LINCH $^{44}$ e WRIGHT; JACKSON ${ }^{58}$ afirmaram que a língua consiste no local mais afetado por estas lesões. Em nossa amostra, os neurofibromas ocorreram principalmente no rebordo alveolar e gengiva seguida pela língua (Tabela 6) e nenhuma lesão central ou intra-óssea foi registrada. A freqüência de neurofibromas na cavidade bucal (18,2\%) em nossa amostra (Tabela 
6) comparativamente às lesões cutâneas $(81,8 \%)$ reflete adequadamente a ocorrência destas lesões na região de cabeça e pescoço como previamente descrito por outros autores $^{8,40}$

Mesmo sendo uma lesão quase sempre com uma evolução clínica benigna, a variante plexiforme do neurofibroma apresenta uma tendência a deformar feixes nervosos maiores, causando freqüentemente alterações cosméticas, dor e deficiências neurológicas ${ }^{43}$. Além disso, os neurofibromas plexiformes que se manifestam como parte da NF-1 possuem maior risco de transformação maligna ${ }^{15,29,43,54,56}$. Os pacientes sindrômicos com história de duração da doença superior a dez anos e apresentando um neurofibroma preexistente apresentam maiores chances de desenvolvimento de um tumor maligno de origem neural ${ }^{54}$. A taxa de transformação neoplásica de um neurofibroma preexistente varia de 2-6\% nos pacientes com NF$1^{15,16,23,43}$.

A perda ou mutação de um ou mais genes supressores de tumor tem sido investigadas como uma das prováveis causas da transformação neoplásica dos neurofibromas isolados ou associados a NF-1 ${ }^{33}$ e a expressão aberrante da proteína p53 foi demonstrada na transição de neurofibroma para tumor maligno da bainha do nervo periférico ${ }^{17}$.

Por outro lado, nos neurofibromas superficiais ou isolados e não associados a NF-1, plexiformes ou difusos, como observados na maioria das lesões de nosso estudo, a freqüência de transformação maligna não está estabelecida ${ }^{16,56}$ mas parece ser menor quando comparada àquelas dos indivíduos portadores de neurofibromatose do tipo $1^{30}$. 
Alguns neurofibromas apresentam significativas alterações morfológicas como atipia celular e maior celularidade sugerindo uma transformação maligna precoce o que pode dificultar o estabelecimento do diagnóstico microscópico entre uma lesão benigna ou maligna. Este tipo de lesão tem sido denominado neurofibroma atípico $^{24,26,43,56}$ sendo geralmente tratada por ressecção cirúrgica não apresentando tendência a recorrência ou metástase ${ }^{26}$. Essas lesões são pouco freqüentes ${ }^{43,56} \mathrm{e} \mathrm{em}$ nossa amostra, mesmo nos neurofibromas mais celularizados não observamos células com características atípicas.

\begin{abstract}
Além das diversas manifestações clínicas os neurofibromas, embora constituídos essencialmente pelos mesmos componentes celulares e matriz extracelular, apresentam microscopicamente diferentes organizações teciduais caracterizando variantes distintas e peculiares ${ }^{43,57,56}$.
\end{abstract}

A variabilidade de manifestações clínicas dos neurofibromas associados ou não às neurofibromatoses estimulam cada vez mais a busca do conhecimento referente à participação dos diferentes componentes celulares na patogênese da lesão.

Os 66 neurofibromas de nossa casuística, analisados em HematoxilinaEosina, consistiam de lesões com celularidade e estroma colagênico variáveis, porém com distribuição tecidual bem delimitada semelhante às lesões descritas por outros autores $^{6,23,43,56,57}$. Morfologicamente, as células apresentavam-se predominantemente fusiformes e difusamente distribuídas caracterizando o neurofibroma difuso (Figura 3). Alguns poucos exemplos da variante plexiforme (Figura 4), como pode ser visualizado na Tabela 7 , foram encontrados na mucosa bucal, sendo um deles parte da manifestação clinica da neurofibromatose-1. 
Os corpúsculos táteis-like de Meissner e Pacini foram observados em ambas as variantes difusa e plexiforme (Figura 3 e 4). Esses pseudocorpúsculos táteis são imunorreativos para a proteína S-100 (Figura 9), sendo encontrados quase sempre nos neurofibromas quando comparados aos schwanomas ${ }^{43}$.

Desde a constatação da célula de Schwann como um dos importantes componentes do neurofibroma ${ }^{16,33,42,43,55,56}$ a patogênese desta lesão tem sido direcionada principalmente, para os estudos das alterações morfológicas, funcionais e genéticas desta célula.

Os recentes avanços genéticos em indivíduos com neurofibromatose do tipo 1 tem demonstrado mutações no gene NF-1 e uma hipótese sustentada por alguns autores $^{16,18,33,36,41,42}$ sugere que todas as células carregam uma mutação constitucional do gene NF-1 e a aquisição de uma segunda mutação somática, por exemplo, nas células de Schwann iniciaria a formação do neurofibroma nestes indivíduos. Esta perda da heterozigose do gene NF-1 que ocorre tardiamente na vida parece ser uma importante etapa no espectro da tumorigênese ${ }^{18}$.

O gene NF-1, localizado no cromossomo 17 é constituído por 60 exons, é considerado um gene supressor de tumor e codifica uma proteína de $250 \mathrm{kDa}$ denominada neurofibromina ${ }^{42}$. Essa proteína funciona inativando o protooncogene p21-ras, um dos responsáveis pelo estímulo mitogênico que resulta em proliferação celular. Em pacientes com NF-1 a inativação dos dois alelos do gene NF-1 nas células de Schwann tem sido associada com elevados níveis de ras ativado, o que justifica o padrão de crescimento contínuo dos neurofibromas nesses pacientes ${ }^{33,42}$. 
Além da perda da neurofibromina devido à inativação de ambos alelos do gene NF-1 nas células de Schwann, existem evidências de que outros eventos adicionais derivados das outras células do neurofibroma são importantes colaboradores na gênese e crescimento dessas lesões. Esses eventos incluem a expressão aumentada de receptores e de fatores de crescimento como o receptor para fator de crescimento derivado de plaqueta, receptor para fator de crescimento epidérmico e fator de crescimento endotelial vascular ${ }^{33}$.

A variabilidade de citocinas e fatores de crescimento presentes nos neurofibromas estimulam também a proliferação de outros componentes celulares induzindo, por exemplo, a neoformação vascular sanguínea ${ }^{33}$. Em nossa casuística moderada ou intensa vascularização sanguínea foi observada, principalmente, de permeio as diferentes células constituintes do neurofibroma (Figura 6).

Uma outra característica microscópica presente nos neurofibromas de cabeça e pescoço consistiu em marcante número de mastócitos com localização predominantemente perivascular. O papel exato dos mastócitos nos neurofibromas não está totalmente estabelecido ${ }^{21,33,39}$.

Em 2003, LARA ${ }^{21}$ ao quantificar os mastócitos e avaliar a expressão bem como a localização do fator de crescimento fibroblástico básico (bFGF) e receptores do fator de crescimento neural (NGFR) em lesões neurais benignas e neuromas traumáticos bucais, constatou que embora em maior número nos neurofibromas, os mastócitos provavelmente contribuem na patogênese destas lesões através de outros mediadores que não o FGF-2 e NGF. 
O mecanismo molecular involvido na migração dos mastócitos nos neurofibromas, em estudos recentes ${ }^{52,60}$, foi fortemente associado à população de célula de Schwann deficiente de neurofibromina que secreta excessivamente um "Kit ligante"(Stem Cell Factor) cujos receptores são expressos pelos mastócitos ${ }^{60,52}$. Entretanto, torna-se importante estabelecer a função dos mastócitos após sua migração induzida pela célula de Schwann. Além das substâncias mitogênicas e angiogênicas incluindo o FGF, VEGF, histamina, heparina, prostaglandina, leucotrienos e enzimas proteolíticas, os mastócitos podem também desempenhar outras funções ou novas interações entre as células ainda desconhecidas ${ }^{52}$.

O caso clínico apresentado de uma paciente com um neurofibroma plexiforme, na boca sem outras manifestações da NF-1, levou-nos a investigar os possíveis mecanismos envolvidos na patogênese desta lesão visando explicar sua ocorrência isolada na boca.

A lesão foi avaliada em coloração de rotina, e caracterizada imunohistoquímicamente com os seguintes anticorpos: S-100, EMA, colágeno IV e CD34. Como observado no neurofibroma plexiforme analisado neste estudo e também documentado na literatura, todas as variantes do neurofibroma e os corpúsculos táteis-like, apresentam células imunopositivas para a proteína S-100 14,36,42,43,55,56. Entretanto, a imunorreatividade ao EMA limitou-se a região perineural circundando os feixes nervosos expandidos (Figura 10A) sugerindo perineuro normal remanescente, pois mesmo com a presença de células ultra-estruturalmente semelhantes às perineurais, nem todos os neurofibromas apresentam reatividade celular ao $\mathrm{EMA}^{43,56}$. A imunopositividade à proteína $\mathrm{CD} 34$ e ao colágeno IV 
apresentou um padrão microscópico característico com marcação, respectivamente, das células fibroblásticas e na região pericelular envolvendo algumas células da matriz (Figuras 10B e 11).

A manifestação bucal do neurofibroma plexiforme periférico, isolado, em pacientes não sindrômicos, é pouco freqüente e apenas alguns exemplos foram descritos associados à glândula submandibular ${ }^{50}$, à língua ${ }^{46}$ ou aderida ao periósteo na região de pré-molares ${ }^{1}$.

Também na pele, poucos neurofibromas plexiformes superficiais não associados à doença de von Recklinghausen foram descritos por ALOI; MASSOBRIO $^{3}$ e FISHER; CHU; McCALMONT ${ }^{14}$, que sugeriram uma natureza hiperplásica hamartomatosa para essas lesões.

O neurofibroma plexiforme embora considerado um sinal patognomônico da neurofibromatose, pode ocorrer como uma lesão isolada e WEISS; GOLDBLUM ${ }^{15}$ afirmaram que uma lesão pequena da variante plexiforme, como ilustrado em nosso caso clínico, não deve ser considerada um estigma da síndrome da neurofibromatose1.

Por outro lado, não podemos descartar a possibilidade da paciente com neurofibroma plexiforme isolado em boca apresentar uma neurofibromatose segmental, como sugerido pelo Dr. Robert J Gorlin* da University of Minnesota, em comunicação pessoal. A presença de um neurofibroma plexiforme sem outros estigmas ou história familiar da NF-1 pode ser o resultado de uma mutação somática local, ocorrendo tardiamente na vida ${ }^{15,41,43}$.

* Comunicação pessoal. Correspondência via e-mail em 22/03/04. 
Esse mecanismo reflete o mosaicismo do gene NF-1 ou de outros genes relacionados a este e parece ser a base da chamada neurofibromatose segmental ou localizada, uma forma anatomicamente limitada da NF-1 ${ }^{15,41}$. Nesses casos além de um neurofibroma o paciente apresenta manchas café-com-leite limitadas ou sardas axilares restritas a uma determinada área corporal, freqüentemente ipsilateral não cruzando a linha média do corpo ${ }^{15,41,43}$. Esses pacientes não transmitem a condição para seus descendentes e desenvolvem complicações da doença somente na distribuição do nervo afetado ${ }^{15,43}$.

Embora, no caso clínico apresentado o neurofibroma plexiforme se caracterizava por ser uma lesão muito mais pontual do que segmental não apresentando outras alterações no segmento nervoso e nenhum outro sinal característico da neurofibromatose, a paciente foi orientada a respeito da possibilidade da ocorrência tardia de alguns sinais da NF-1 segmental.

Uma investigação genética visando detectar as alterações do gene NF-1 poderia auxiliar no diagnóstico de neurofibromatose na referida paciente. Entretanto, o gene NF-1 possui 60 exons e a sua extensão bem como a heterogeneidade do sequenciamento do DNA das possíveis mutações deste gene ${ }^{14,41}$ tem, atualmente, limitado a viabilidade dos testes genéticos como um procedimento laboratorial rotineiro. Alem do mais, segundo PERRY et $\mathrm{al}^{36}$ muitos neurofibromas plexiformes e talvez a maioria dos neurofibromas cutâneos não apresentam alterações genéticas detectáveis, sendo por isso, considerados mais hiperplásicos do que neoplásicos. Esses autores sugerem ainda que alguns desses neurofibromas plexiformes podem ocultar mutações inativas não detectáveis pelo FISH (hibridização in situ com 
fluorescência) e LOH (perda da heterozigoze) envolvendo alterações de outros genes além do NF-1 ou apresentam clones neoplásicos mínimos que induzem um obscuro processo reativo incluindo os fibroblastos não neoplásicos, as células perineurais-like e as células de Schwann intraneurais nativas.

As teorias descritas acima demostraram que a patogênese dos neurofibromas, particularmente da variante plexiforme, ainda não está completamente estabelecida. Os nossos resultados incluindo o caso clínico apresentado suporta a teoria de que os neurofibromas periféricos e isolados, cutâneos ou mucosos, com comportamento clínico benigno em pacientes sem outras manifestações da NF-1 apresentam uma natureza mais hiperplásica hamartomatosa do que neoplásica.

Entretanto, outros estudos são necessários para uma melhor definição dos mecanismos genéticos ou não envolvidos na formação e desenvolvimento dessas lesões, principalmente quando de sua ocorrência superficial, isolada e pontual, não associada a neurofibromatose do tipo 1 . 
Conclusão 


\section{CONCLUSÃO}

A análise dos neurofibroma localizados na região de cabeça e pescoço permitiu verificar:

- uma maior freqüência das lesões em pacientes com idade acima de 40 anos sendo a maioria do gênero feminino;

- uma predominância de lesões cutâneas em relação à mucosa bucal, sendo a gengiva e o rebordo alveolar os locais mais afetados;

- uma maior ocorrência de lesões na pele e mucosa bucal, únicas, isoladas e de pequenas dimensões e com aparecimento tardio, sendo as lesões múltiplas quase sempre associadas a NF-1;

- um comportamento clínico benigno tanto para as lesões cutâneas como mucosas caracterizadas pela ausência de recidiva;

- microscopicamente, uma maior ocorrência de neurofibroma difuso comparado a variante plexiforme;

- presença de corpúsculos táteis-like tanto nas lesões difusas como plexiformes além de, uma marcante vascularização sanguínea e um intenso número de mastócitos de permeio a lesão;

- uma imunomarcação característica da proteína S-100, EMA, colágeno IV e CD34 no neurofibroma plexiforme isolado da mucosa bucal. 
Portanto com base nesses resultados e no caso clínico apresentado podemos concluir que os neurofibromas na região de cabeça e pescoço, particularmente a variante plexiforme, podem ocorrer de forma isolada não associada à doença de von Recklinghausen o que sugere uma natureza hamartomatosa para estas lesões, cuja patogênese precisa ser melhor investigada. 
Anexos 


\section{ANEXO 1}

\section{TÉCNICA IMUNO-HISTOQUÍMICA}

A técnica imuno-histoquímica utilizada no Laboratório de Anatomia Patológica e Citológica do Hospital de Base de Bauru foi baseada no método LSAB com os seguintes anticorpos primários: S-100 (DAKO, Carpinteria 1:800), EMA (DAKO, Carpinteria 1:80), CD34 (DAKO, Carpinteria 1:50) colágeno IV (DAKO, Carpinteria 1:80).

Os cortes de $4 \mu \mathrm{m}$ foram desparafinizados em xilol, hidratados em três banhos de álcool absoluto seguido por imersão em PBS por cinco minutos.

A atividade da peroxidase endógena foi bloqueada por $\mathrm{H}_{2} \mathrm{O}_{2}$ a $3 \%$ em PBS, seguida por banho de PBS. A recuperação antigênica foi realizada para o CD34 pela imersão das lâminas em solução de tampão-citrato $10 \mathrm{mM}, \mathrm{pH}$ 6,0 e aquecimento em microondas em três ciclos de cinco minutos, e para os demais marcadores utilizou-se a digestão enzimática (tripsina $0,25 \%$ em PBS) por 30 minutos a $4^{\circ} \mathrm{C}$.

A incubação com os anticorpos primários foi feita overnight e em seguida as lâminas foram incubadas com o anticorpo secundário biotinilado (DAKO, StreptABC-Complex) por 45 minutos. A reação antígeno-anticorpo foi visualizada pela solução de 3'3 diaminobenzidine tetrahydrochloride (DAB) por cinco minutos ao abrigo da luz. A última etapa consistiu da contracoloração, feita com hematoxilina de Harris a 30\% durante um minuto, seguida por três banhos de álcool absoluto e três de xilol. 
_ Referências Bibliográficas 


\section{REFERÊNCIAS BIBLIOGRÁFICAS*}

1. ALATLI, C. et al. Solitary plexiform neurofibroma of the oral cavity: case report. J Maxillofac Surg, v.25, n.5, p. 379-80, Apr 1996.

2. ALBERNAZ, M.S.; PRATT, M.F.; GAREN, P.D. Intraparotid facial nerve neurofibroma: a case report and literature review. Otolaryngol Head Neck Surg, v.102, n.4, p. 413-5, Apr 1990.

3. ALOI, F.G.; MASSOBRIO, R. Solitary plexiform neurofibroma. Dermatologica, v.179, n.2, p.84-6, 1989.

4. ARIZA, A.; BILBOA, J.M.; ROSAI, J. Immunohistochemical detection of epitelial membrane antigen in normal perineurial cells and perineurioma. Am $\mathbf{J}$ Surg Pathol, v.12, n.9 , p.678-83, Sept 1988.

5. BOCCA, M. et al. Neurofibroma della mandibola: revisione della letteratura e prezentaziona di un caso clinico. Minerva Stomatol, v.39, n.8, p. 675-7, Aug 1990.

6. CAWSON, R.A. et al. Soft tissue tumors. In:__, Lucas pathology of tumors of the oral tissues. Londres. Churchill Livingstone, 5.ed. 1998. Cap.8, p.275-82.

7. CHEN, S.Y.; MILLER, A. Neurofibroma and schwannoma of the oral cavity. Oral Surg, v.47, n.6, p.522-8, Jun 1979.

\footnotetext{
* Normas recomendadas para uso no âmbito da Universidade de São Paulo, com base no documento "Referências bibliográficas: exemplos"emanada do Conselho Supervisor Integrado de Bibliotecas da USP, em reunião de 20 de setembro de 1990
} 
8. CHERRICK, H.M.; EVERSOLE, L.R. Benign neural sheath neoplasm of the oral cavity. J Oral Surg, v.32, n.6, p.900-1, Dec 1971.

9. CHI, T.W.; LIN, J.C.; SHIH S.L. Neurofibroma: an unusual presentation. Neuroradiology, v.35, n.8, p.614-5, 1993.

10. CHOUBAL, A. et al. CD 34 immunoreactivity in nervous system tumors. Acta Neuropathol, v.88, p.454-8, 1994.

11. DASCHNER, K. et al. Clonal origin of tumor cells in a plexiform neurofibroma with LOH in NF1 intron 38 and in dermal neurofibromas without $\mathrm{LOH}$ of the NF1 gene. Biochem Biophys Res Commun. v.234, n.2, p.346-50, May 1997.

12. DIBLE, J.H. Verocay bodies and pseudo-Meissnerian corpuscles. J Pathol Bacteriol. v.85, p.425-33, Apr 1963.

13. ELLIS, G.L.; AUCLAIR, P.L.; GNEPP, D.R.. Benign mesenchymal neoplasms. In: _ Surgical pathology of the salivary glands. Philadephia, Saunders, 1991. Cap.28, p.496-7.

14. FISHER, D.A.; CHU, P.; McCALAMONT, T. Solitary plexiform neurofibroma is not pathognomonic of von Recklinghausen s neurofibromatosis: a report of a case. Int J Dermatol, v.36, n.6, p.439-42, June 1997.

15. GORLIN, R.J.; COHEN, M.M.; LEVIN, L.S. Hamartoneoplastic syndromes. In:__ Syndromes of the head and neck 3.ed.. Oxford,. Oxford University Press, 1990. Cap.12, p.392-9. 
16. HADJU, S.I. Peripheral nerve sheath tumors. Cancer, v.72, n.12, p.3549-52, Dec 1993.

17. HALLING, K.C. et al. p53 expression in neurofibroma and malignant peripheral nerve sheath tumor. An immunohistochemical study of sporadic and NF-1 associated tumor. Am J Clin Pathol, v.106, n.3, p.282-8, Sept 1996.

18. HAPPLE, R. Large plexiform neurofibromas may be explained as a type 2 segmental manifestation of neurofibromatosis 1 /Letter/. Am J Med Genet, v.98, n.4, p.363-4, 2001.

19. JURECKA, W. Tactile corpuscle-like structures in peripheral nerve sheath tumors in plastic embedded material. Am J Dermatopathol, v.10, n.1, p.74-9, Feb 1988.

20. JURECKA, W et al Tactile corpuscle-like structures in a case of plexiform neurofibromatosis. Arch Dermatol Res v.266, n.1 , p.43-50, Aug 1979.

21. LARA, V.S. Estudo comparativo da expressão de triptase de mastócitos, de fator de crescimento fibroblástico básico (bFGF) e do receptor de crescimento neural (NGFR) em lesões neurais bucais. Bauru, 2003. 75p. Tese (Livre-Docência) Faculdade de Odontologia de Bauru, Universidade de São Paulo.

22. LAZARUS, S.S.; TROMBETTA, L.D. Ultrastructural identification of a benign perineurial cell tumor. Cancer, v.41, n.5, p.1823-9, May 1978. 
23. LEVER, W.F.; LEVER G.S. Tumors of neural tissue In:

Histopathology of the skin. 7.ed. Philadelphia, J. B. Lippincott, 1990. Cap.32, p.739-45.

24. LIAPIS, H.; DEHNER, L.P.; GUTMAN, D.H. Neurofibroma and cellular neurofibroma with atypia: a report of 14 tumors. /Letter/ Am J Surg Pathol, v.23, n.9, p. 1156-63, Sept 1999.

25. LIAPIS, H.; MARLEY, E.F.; LIN, Y.DEHNER, L.P. p53 and Ki-67 proliferating cell nuclear antigen in benign and malignant peripheral nerve sheath tumors in children. Pediatr Dev Pathol, v.2, n.4 , p. 377-84, July/Aug 1999

26. LIN, B.T.Y.; WEISS, L.M.; MEDEIROS, L.J. Neurofibroma and cellular neurofibroma with atypia: a report of 14 tumors. Am J Surg Pathol, v.21, n.12, p. 1443-9, 1997.

27. LOUFTY, W.G. et al. Trigeminal nerve neurofibroma: case report. J Oral Maxillofac Surg, v.35, p. 733-8, Sept 1977.

28. NEEDLE, M.N. et al. Prognostic signs in the surgical management of plexiform neurofibroma: the Children's Hospital of Philadelphia experience, 1974-1994. J Pediatr, v.131, n.5, p. 678-82, Nov 1994.

29. NEUROFIBROMATOSIS: Conference Statement. National Institutes of Health Consensus Development Conference. Arch Neurol, v.45, n. 5, p.575-8, May 1988. 
30. NEVILLE, B.W. et al. Soft tissue tumors. In: . Oral and maxillofacial pathology. Philadelphia, W. B. Saunders, ed 1995. Cap.12, p. 380-5.

31. NICOL, J.W.; YARDLEY, M.P.J.; PARKER, A.J. Plexiform neurofibroma: an unusual cause of neck lump in a child. Br J Clin Pract, v.48, n.2, p.110-1, Mar/Apr 1994.

32. ODELL, E.W.; MORGAN, P.R. Some syndromes with oral presentations. In: , Biopsy pathology of the oral tissues. Londres, Chapman \& Hall Medical, 1998. Cap.14, p.444.

33. PACKER, R.J.; GUTMANN, D.H.; RUBENSTEIN, A. Plexiform neurofibromas in NF1: toward biologic based therapy. Neurology, v.58, n.10, p.1461-70, May 2002.

34. PEETERMANS, J.F.E. et al. Neurofibroma of the vagus nerve in the head and neck: a case report. Head and Neck, v.13, n.1, p.56-61, Jan/Feb 1991.

35. PERENTES, E.; RUBINSTEIN, L.J. Immunohistochemical recognition of human neuroepithelial tumors by anti-Leu 7 (HNK-I) monoclonal antibody. Acta Neuropathol. v.69, n.3-4, p.227-33, 1986.

36. PERRY, A. et al. NF1 deletions in S-100 protein-positive and negative cells of sporadic and neurofibromatosis 1 (NF1)- Associated plexiform neurofibromas and malignant peripheral nerve sheath tumors.Am J Pathol, v.159, n.1, p.5761, July 2001. 
37. POLLACK, R.P. Neurofibroma of the palatal mucosa: case report. J Periodontol, v.61, n.7, p.456-8, July 1990.

38. PRESCOTT, G.H.; WHITE, E. Solitary, central neurofibroma of the mandible: report of case and review of the literature. J Oral Surg, v.28, n.4, p. 305-9, Apr 1970.

39. RICCARDI, V. Mast cell stabilization to decrease neurofibroma growth. Preliminary experience with ketotifen. Arch Dermatol, v.123, n.8, p. 1011-6, Aug 1987.

40. RICHARDS, D. Neurofibroma of the oral cavity. Br J Oral Surg, v.21, n.1, p.3643, Mar 1983.

41. RUGGIERI, M.; HUSON,S.M. The clinical and diagnostic implications of mosaicism in the neurofibromatoses. Neurol, v.56, n. , p.1433-43, 2001.

42. RUTKOWSKI, J.L. et al Genetic and cellular defects contributing to benign tumor formation in neurofibromatosis type 1. Hum Mol Genet, v.9, n.7, p.1059-66, Apr 2000.

43. SCHEITHAUER, B.W.; WOODRUFF, J.M.; ERLANDSON, R.A. Tumors of the peripheral nervous system. Atlas of tumor pathology. Washington, D.C., Armed Forces Institute of Pathology, 1999. 415 p.

44. SHACK, R.B.; REILLEY, A.F.; LYNCH, J.B. Neurofibromas of head and neck. South Med J, v.78, n.7, p. 801-4, July 1985. 
45. SHARAWY, A.; SPRINGER, J. Central neurofibroma occuring in the mandible. Oral Surg Oral Med Oral Pathol, v.25, n.6, p.817-21, June 1968.

46. SHARMA, S.C.; SRINIVASAN,S. Isolated plexiform neurofibroma of tongue and oropharynx: a rare manifestation of von Recklinghausen's disease. J Otolaryngol, v.27, n.2, p.81-4, Apr 1998.

47. SHIMOYAMA, T. et al. Solitary neurofibroma of the oral mucosa: a previously undescribed variant of neurofibroma. J Oral Sci, v.44, n.1, p.59-63, Mar 2002.

48. SKOUTERIS, C.A; SOTEREANOS, G. Solitary neurofibroma of the maxilla: report of a case. J Oral Maxillofac Surg, v.46, n.8, p.701-5, Aug 1988.

49. STEWART, A.; BAILEY, M.W. Neurofibroma of the inferior alveolar nerve: diagnostic and management difficulties. Br J Oral Maxillofac Surg, v.30, n.1, p. 56-8, Feb 1992.

50. TSUTSUMI, T.; TSUNEYUKI,O.; KOMATSUZAKI,A. Solitary plexiform neurofibroma of the submandibular salivary gland. J Laryngol Otol, v.110, n.12, p.1173-5, Dec 1996.

51. Verocay J. Zur kenntnis der Neurofibrome. Beitr Pathol Anat Allg Pathol, v.48, p.1-69, 1910 apud SCHEITHAUER, B.W.; WOODRUFF, J.M.; ERLANDSON, R.A. ${ }^{41}$

52. VISKOCHIL, D.H. It takes two to tango: mast cell and Schwann cell interactions in neurofibromas. J Clin Invest, v.112, n.12, p.1791-3, Dec 2003. 
53. von RECKLINGHAUSEN, F.D. Uber die multiplen fibromeder haut und ihre beziehung zuden multiplen neuromen.- Berlin. A. Hirschwald, 1882 apud SCHEITHAUER, B.W.; WOODRUFF, J.M.; ERLANDSON, R.A. ${ }^{41}$

54. WEBER, A.; MONTANDON, C.; ROBSON, C.D. Neurogenic tumors of the neck. Radiologic Clinics of North America, v.38, n.5, p. 1077-90, Sept 2000.

55. WEEDON, D. Neural and neuroendocrine tumors. In: , Skin pathology. 2.ed. London. Churchill Livingstone, 2002. Cap.37, p.983-6.

56. WEISS, S.W.; GOLDBLUM, J.R. Benign tumors of peripheral nerves. In:__ Soft tissue tumors. 4.ed. Missouri Mosby, 2001. Cap.30, p.1111-46.

57. WEISS, S.W.; NICKOLOFF, B.J. CD-34 is expressed by a distinctive cell population in peripheral nerve, nerve sheath tumors, and related lesions. Am J Surg Pathol, v.17, n.10, p.1039-45, Oct 1993.

58. WEISS, S.W. et al. Neural Tumours. In: , Histological typing of soft tissue tumours. 2.ed. Berlin. Springer-Verlag, 1994. Cap.10, p.38-9.

59. WRIGHT, BA.; JACKSON, J. Neural tumors of the oral cavity. Oral Surg, v.49, n.6, p.509-22, Apr 1980.

60. YANG, F.C. et al Neurofibromin-deficient Schwann cells secrete a potent migratory stimulus for $\mathrm{Nf}^{+/-}$mast cells. J Clin Invest, v.112, n.12, p.1851-61, Dec 2003. 
Abstract 


\section{ISOLATED NEUROFIBROMAS IN THE HEAD AND NECK: CLINICAL AND HISTOPATHOLOGICAL CONSIDERATIONS}

The neurofibroma occurs, in the head and neck region, as isolated or multiple lesion, frequently associated with neurofibromatosis. The aim of this study was to analyse the clinical and histopathological features of neurofibromas, particularly the plexiform type, located in the skin and in oral mucosa, and to discuss their pathogenesis as well as clinical management of isolated, sporadic lesion, unassociated with neurofibromatosis-1 (NF-1). Sixty six cases of neurofibromas from the files of Stomatology Department- Area of Pathology of the Bauru School of Dentistry and Lauro de Souza Lima Research Institute, were retrospectively reviewed. Clinical data, therapy and follow-up information were obtained from the medical records. Histopathological analysis of the neurofibromas was performed on paraffin sections routinely stained with hematoxilin-eosin. Some features such as cellular morphology, tissue organization, distribution of inflammatory infiltrate, presence of mast cells, and tactile-like bodies were investigated. The results showed a high frequency of cutaneous lesions $(81,8 \%)$, as compared with those of the oral mucosa $(18,2 \%)$, occurring mainly in females and patients older than 40 years. Isolated neurofibromas were found in $51.2 \%$ of patients and multiple lesions $(37,2 \%)$ were often associated with the NF-1 $(28.0 \%)$. In addition $27.9 \%$ of patients presented neurofibromas in the oral mucosa, being the gingival mucosa and alveolar ridge the most commonly affected sites. Only two plexiform neurofibromas $(3,0 \%)$, both arising in oral mucosa, were found and one of them, was associated with the von Recklinghausen neurofibromatosis. Microscopically, diffused neurofibromas occur more frequently than the plexiform variant, and tactile-like bodies seen in both types. These results demonstrated that neurofibromas, particularly, the plexiform type, can occur in the skin and oral mucosa as a isolated lesion, not associated with the NF-1. The benign clinical behavior of the isolated, sporadic neurofibroma unassociated with neurofibromatosis, in the head and neck region, suggests a hyperplastic hamartomatous nature, whose pathogenesis needs to be further investigated. 


\section{Universidade de São Paulo Faculdade de Odontologia de Bauru}

Al. Dr. Octávio Pinheiro Brisolla, 9-75 - Bauru-SP - CEP 17012-901 - C.P. 73 PABX (0XXI4)235-8000 - FAX (0XX14)223-4679

Comile de Éfica em Pesquisa

Processo $n^{\circ} 149 / 2003$

Bauru, 02 de dezembro de 2003

Senhora Professora,

O projeto de pesquisa encaminhado a este Comitê de Ética em Pesquisa em Seres Humanos, denominado "Neurofibroma isolado na região de cabeça c pescoço: consideraçōes clínicas e histopatológicas", de autoria de Luciana Sassa Marocchio e Prof. Dr. Raul Negrão Fleury (colaborador), que será desenvolvido sob sua orientaçăo, foi enviado ao relator para avaliação.

$\mathrm{Na}$ reunião de 26 de novembro de 2003 o parecer do relator, aprovando o projeto, foi aceito pelo Comitê, considerando que não existem infrações éticas pendentes.

Informamos que após o envio do trabalho concluido, este Comitê enviará o parecer final, que será utilizado para publicação do trabalho.

Atenciosamente,

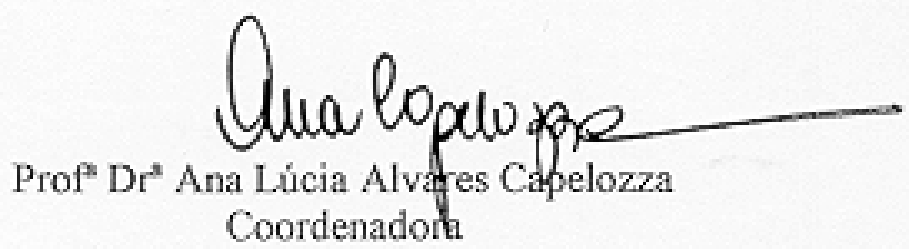

$\mathrm{Ilm}^{\mathrm{a}} \mathrm{Sr}^{\mathrm{a}}$ Prof $^{\mathrm{a}} \mathrm{Dr}^{\mathrm{x}}$ Denise Tostes Oliveira

DD. Docente do Departamento de Estomatologia 